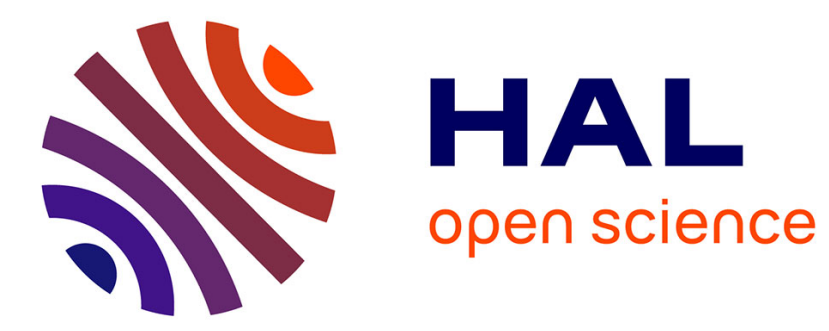

\title{
Aid for trade in developing countries: complex linkages for real effectiveness
}

Marilyne Huchet, Anna Lipchitz, Audrey Rousson

\section{To cite this version:}

Marilyne Huchet, Anna Lipchitz, Audrey Rousson. Aid for trade in developing countries: complex linkages for real effectiveness. African Development Review, 2009, 21 (2), pp.243-290. 10.1111/j.14678268.2009.00210.x . hal-00729947

\section{HAL Id: hal-00729947}

\section{https://institut-agro-rennes-angers.hal.science/hal-00729947}

Submitted on 31 May 2020

HAL is a multi-disciplinary open access archive for the deposit and dissemination of scientific research documents, whether they are published or not. The documents may come from teaching and research institutions in France or abroad, or from public or private research centers.
L'archive ouverte pluridisciplinaire HAL, est destinée au dépôt et à la diffusion de documents scientifiques de niveau recherche, publiés ou non, émanant des établissements d'enseignement et de recherche français ou étrangers, des laboratoires publics ou privés. 


\section{Aid for Trade in Developing Countries: Complex Linkages for Real Effectiveness}

Marilyne Huchet-Bourdon ${ }^{\mathrm{a}, \mathrm{b}}$, Anna Lipchitz ${ }^{\mathrm{c}}$ and Audrey Rousson ${ }^{\mathrm{d}}$

\section{Acknowledgements}

The authors extend their particular thanks to Céline About, Caroline Balossier, Bastien Bedossa, Olivier Cadot, Jean-Raphaël Chaponnière, Nassim Oulmane, Eric Jourcin, Hervé Gallèpe, Rémi Lang, Mihoub Mezouaghi, Ben Idrissa Ouedraogo, Serge Perrin and Mustapha Sadni Jallab for their judicious advice. They also thank participants to the African Economic Conference at Addis Ababa (Ethiopia) on November 2007, and the anonymous referee for their helpful comments.

\footnotetext{
${ }^{a}$ AGROCAMPUS OUEST, UMR1302, F-35000 Rennes, France.

${ }^{\mathrm{b}}$ INRA, UMR1302, F-35000 Rennes, France.

${ }^{c}$ Permanent mission of France to the United Nations, Economist, New York, France (anna.lipchitz@ missioneco.org)

${ }^{\mathrm{d}}$ AFD, Consultant, Paris, France (rousson_audrey@yahoo.fr)

Corresponding Author:

Marilyne Huchet-Bourdon, AGROCAMPUS OUEST- UMR1302 SMART - 65 rue de St Brieuc, CS 84215 - 35042

Rennes Cedex - France Tel: +33 (0)2 234855 98, E-mail: marilyne.huchet-bourdon@agrocampus-ouest.fr
} 


\title{
$\underline{\text { Résumé }}$
}

L'aide au commerce, présentée comme un nouvel outil de développement prometteur, vise à soutenir l'intégration commerciale des pays en développement. Il manque néanmoins à cette aide, pour asseoir son efficacité et respecter les engagements politiques des donateurs, une dimension stratégique. D'un point de vue théorique, cette étude présente les différentes catégories d'aide au commerce et analyse les relations entre IDE, aide au commerce et développement. Elle propose également une typologie des besoins liés au commerce pour un panel de pays afin de guider les bailleurs de fonds dans la définition de leurs stratégies d'offre. Cette typologie met en avant des disparités aux niveaux national et régional, ainsi qu'une faible intégration régionale. Les besoins liés au commerce, particulièrement forts pour les régions de l'Afrique de l'Ouest et de l'Afrique de l'Est, sont importants dans le secteur des infrastructures. Cet article souligne également l'importance d'affiner la formulation des demandes réelles du côté des bénéficiaires, de structurer l'offre des bailleurs en fonction de leurs propres compétences et d'approfondir la coordination entre les différentes parties prenantes, dont acteurs publics et acteurs privés. Enfin, une libéralisation plus poussée des échanges ne suffira pas, à elle seule, à enclencher une croissance forte et à améliorer la répartition géographique et sectorielle des IDE. Des facteurs comme la stabilité politique, l'environnement des entreprises, l'infrastructure matérielle, les institutions et le capital humain sont également des dimensions fondamentales. En particulier, une cohérence entre politiques commerciales, sectorielles, macroéconomiques et fiscales est impérative, pour chaque pays et chaque région mais également entre pays industrialisés et PED.

\begin{abstract}
$\underline{\text { Abstract }}$
Aid for trade is intended to support the integration of developing countries into the world trading system. Although this form of aid is being hailed as a promising new development tool, it lacks the strategic dimension that it needs if it is to be truly effective and fulfil donors' policy commitments. From a theoretical perspective, this paper presents the various aid-for-trade categories and analyses the linkages between foreign direct investment, aid for trade and development. It also presents a typology of trade-related needs for a panel of countries, to serve as a guide for donors in formulating their aid supply strategies. This typology reveals a number of disparities between countries and regions, as well as a low level of regional integration. Trade-related needs are particularly significant in West Africa and East Africa, and substantial in the infrastructure sector. This paper also stresses the importance of refining the formulation of actual demand by beneficiaries, structuring the aid supply in accordance with donors' specific areas of expertise and enhancing coordination among the various stakeholders, both public and private. Lastly, further trade liberalisation will not by itself suffice to generate strong growth and improve the geographical and sectoral distribution of foreign direct investment. Factors such as political stability, the business climate, physical infrastructure, institutions and human capital also play a fundamental role. Of particular importance is the coherence of trade, sectoral, macroeconomic and tax policies, not only within each country and region but also between industrialised and developing countries.
\end{abstract}




\section{Introduction}

Since 23 July 2008, the World Trade Organisation (WTO) has had 153 member countries, accounting for over $97 \%$ of world trade. The WTO encourages its members to adopt common rules in order to minimise the risk of trade wars. In theory, all countries derive mutual benefits from such reforms; thus, the more countries reform their trade policies, the greater the benefits are supposed to be. Building a trade system that encompasses the majority of the world's countries is therefore a matter for international co-operation, and donors have an interest in helping countries join in. However, the gains are not distributed equally across countries, accession to the WTO is costly and many participants still carry very little weight in WTO negotiations (Mendoza and Bakadur, 2002). Despite tariff preference systems and professed market opening, trade liberalisation has not brought the expected results. The least developed countries (LDCs) are falling further behind in terms of competitiveness; some developing countries (DCs) are making no progress on integration into the global market; and despite the efforts of their governments, inflows of foreign direct investment (FDI) are not about to arrive.

Recognition of this situation has initiated far-reaching changes in the formulation of aid policies. Within the category of official development assistance (ODA), aid for trade (AfT), which was officially endorsed at the 6th ministerial conference in Hong Kong in December 2005, is increasingly pointed to as a promising new development tool. It is an essential component of global ODA (21\% in 2006 , or about $\$ 22$ billion), having the same stature as health aid, food aid and educational aid. It may be described as funding in support of efforts (in a wide variety of areas) to build the trade capacity of DCs, particularly the LDCs. Apart from the activity of multilateral institutions and trust funds, most AfT programmes are designed by bilateral donors. In view of the importance of AfT, as well as donor policy statements concerning an increase in such aid and the need to fulfil their obligations under the Paris Declaration, donors will need to develop AfT strategies.

This paper presents a method for guiding donors in defining such strategies but also developing country governments for helping them to manage their development policies. Throughout, special attention is given to FDI in order to gain a deeper understanding of the linkages between trade, FDI and development. In addition, the paper presents a typology aimed at identifying the needs of beneficiary countries in order to set geographical and sectoral priorities. The suggestion of a strategic approach could benefit both to donors and partner countries, and it would allow to be in line with the Paris Declaration on Aid Effectiveness of 2005. Indeed, country ownership, and the partnership between countries for instance are key factors to accelerate progress on aid effectiveness. This has been again recalled in the 2008 Accra Agenda for Action. First, this typology would help donors to improve project selection within their respective financing capacities, and to be in line with beneficiary countries'priorities. That would strengthen co-ordinated actions between donors and the developing countries. Second, it would give some information to developing country governments on their priorities to incite them to take stronger leadership of their own development policies.

The first part of the paper presents AfT as a tool for increasing trade, and hence for fostering development. Next, analysis of the current situation reveals the absence of an AfT strategy that links trade with development. The paper concludes by outlining some thoughts on such a strategy for the attention of AfT donors. 


\section{From "trade, not aid" to "aid for trade"}

The lessons of history and advances in economics have brought radical changes in trade cooperation policies. The "trade, not aid" principle is now out of date. Mere trade preferences are not enough: not only do such systems need to be reformed ${ }^{1}$, but at the same time, each country must expand its productive capacity, comply with all trade regulations, factor in the trade policies of the countries already present on the global market and eliminate infrastructure-related trade barriers. It was considerations such as these that first gave rise to AfT, which is supposed to help DCs become better integrated into the international trading system.

\subsection{Building productive capacity}

\subsubsection{Market opening: the theoretical benefits and the reality}

In theory, trade encourages economies of scale - and thereby productivity gains, technology diffusion and investment - as well as improving incentives for development (Fontagné and Guérin, 1997; Frankel and Romer, 1999; Rodriguez and Rodrik, 2000; Sachs and Warner, 1995). The formation of regional trade blocs also promotes growth by generating economies of scale. Moreover, it encourages countries to achieve macroeconomic convergence, with a view to creating a favourable environment for international competition. It promotes macroeconomic stability by encouraging control of inflation, trade deficits and exchange rates. Consequently, it is conducive to reform of legislative and regulatory frameworks, and the resulting improvement in the quality of institutions or governance should theoretically have a significant impact on growth rates (Hall and Jones, 1999; Acemoglu et al., 2000; Easterly and Levine, 2003; Rodrik et al., 2004).

According to these theoretical considerations, reducing the tariff barriers applied to DCs should enable them to become better integrated into the global market. Their average level of trade integration and their dependence on the outside world may be proxied by the share of exports in their GDP. According to this indicator, all developing regions ${ }^{2}$ except East Africa are markedly more open and more dependent on the outside world than are the OECD countries (Figure 1).

\footnotetext{
${ }^{1}$ Trade preferences do stand in need of improvements, such as harmonisation, broader product coverage, lower transaction costs and revised rules of origin. The erosion of such preferences has made them less important, however, and this paper therefore focuses on AfT.

${ }^{2}$ The following regions are studied here: North Africa, West Africa, Central Africa, East Africa, Southern Africa, the Association of South-East Asian Nations (ASEAN) and the Caribbean (see Appendix 3). These are the regions that have signed free trade agreements with the European Union or will do so in the near future.
} 
Figure 1: Trade characteristics of regions (average of 2002, 2003 and 2004 data, \% of GDP)

Source: WDI.

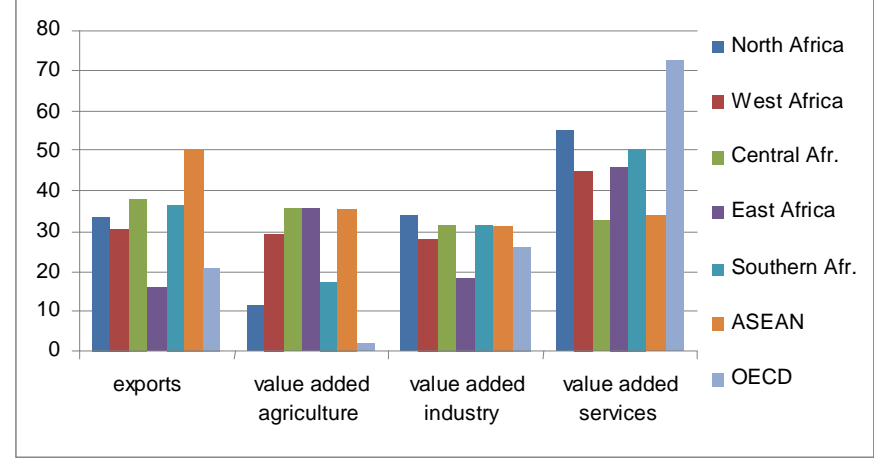

Note: ASEAN: Association of South-East Asian Nations; OECD: Organisation for Economic Co-operation and Development.

Where development co-operation policies are concerned, the European Union, Japan, the United States and Canada have signed a number of preferential agreements with DCs. As such preferential access favours economic development and trade, it should enhance exporting DCs' competitive advantage and thus help to raise their growth rates. The formation of regional blocs and the establishment of rules of origin should also facilitate intra-regional trade and stability.

And yet, although all the right conditions for trade opening seem to exist, economic takeoff has not followed. To be sure, exports have increased in absolute terms, allowing some countries to make a success of trade. Over the 1960-2004 period, exports from sub-Saharan Africa rose from $\$ 5.7$ billion to $\$ 144$ billion, and those from North Africa and the Middle East jumped from \$2.9 billion to \$177 billion. As a share of the world market, however, sub-Saharan Africa's trade has been declining ever since the 1960s (Figure 2). From $4.5 \%$ of world trade in 1960, it had fallen to $1.5 \%$ in 2004 . For North Africa and the Middle East, the trend is also downwards, despite the increase recorded at the time of the oil shocks.

Figure 2: Share of sub-Saharan Africa and Middle East/North Africa in exports to rest of world

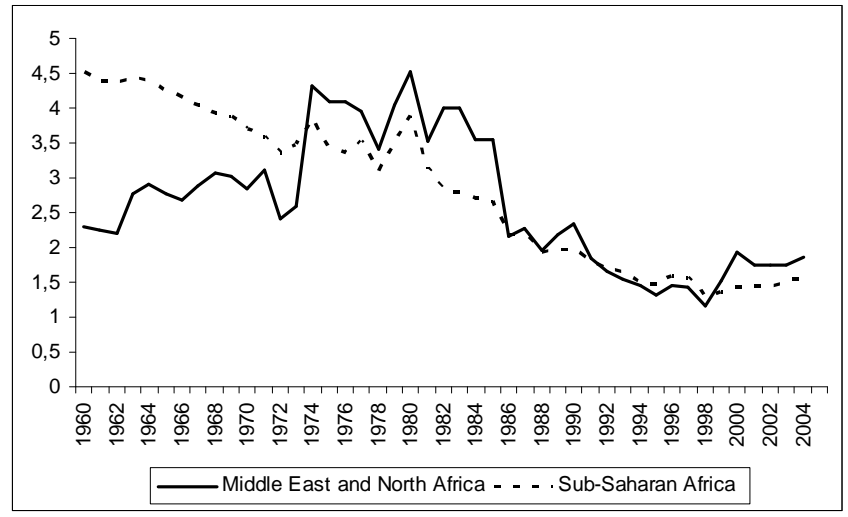

Source: WDI. 
Moreover, economic opening has not brought any considerable improvement in the sectoral breakdown of value added. The average for the six regions listed above is $28 \%$ of GDP for agriculture and $44 \%$ for services. By way of comparison, in the OECD countries agriculture accounts for less than $2 \%$ of GDP and services for $72 \%$. Lastly, export growth has only in a few cases been accompanied by sustained poverty reduction ${ }^{3}$.

Thus, if trade is to contribute to poverty reduction in DCs, trade integration should be an accompaniment to national development rather than vice versa: a development-oriented approach to trade will be more effective than a trade-oriented approach to development. The DCs, and more especially the LDCs, need aid in order to build production capacities ${ }^{4}$ that will promote national development. According to UNCTAD, the fundamentals that govern the development of productive capacity - capital accumulation, technological progress and structural change - have to this point been extremely weak in most LDCs.

\subsubsection{Low foreign direct investment despite strong incentives}

Like investment in general, FDI is a growth factor, affecting both overall demand and production capacity ${ }^{5}$. Opening up more quickly to FDI not only encourages capital inflows but also increases export market opportunities. Wilson and Cacho (2007) use econometric analysis and case studies ${ }^{6}$ to examine the relationship between FDI, trade and trade-related policy. Generally speaking, policies that tend to liberalise trade flows can help to increase FDI and hence development, and conversely. In the OECD countries, customs duty and price supports may influence the geographical distribution of FDI. Such investment may also serve as a means of avoiding or circumventing customs duty. Another possibility is for enterprises from one country to invest in another country to take advantage of the latter's tariff preferences with respect to a third country. Participation in a regional free trade agreement or customs union can open up investment opportunities.

DCs are making ever greater efforts to attract and profit from FDI (UNCTAD, 2004, 2006a, $2006 b, 2007 a, 2007 b)$. As of end-2003, there were over 2,200 bilateral investment agreements involving a total of 176 countries. The number of bilateral, regional or inter-regional trade agreements that directly or indirectly affect investment is also increasing. In addition, most countries do not stop at establishing a national legal framework designed to remove barriers to FDI, but also conclude international investment agreements at various levels (bilateral, regional and multilateral) in order to make themselves more attractive to foreign investors. The data ${ }^{7}$ show, however, that FDI flows are primarily directed towards the developed countries.

\footnotetext{
${ }^{3}$ See Cling (2006) for a detailed review of the literature on this subject.

${ }^{4}$ Production capacities may be defined as "the productive resources, entrepreneurial capabilities and production linkages which together determine the capacity of a country to produce goods and services and enable it to grow and develop" (UNCTAD, 2006c).

5 According to the OECD definition, FDI is an activity whereby an investor resident in one country acquires a lasting interest in an entity resident in another country, with substantial influence over its management. This may involve creating an entirely new company (greenfield investment) or, more often, changing the ownership status of existing enterprises through mergers and acquisitions. Some other types of financial transactions between related companies - particularly reinvestment of the earnings of the investment enterprise, or other capital transfers - are also defined as FDI.

${ }^{6}$ Countries studied: Ghana, Mozambique, Tunisia and Uganda.

${ }^{7}$ According to the UNCTAD database. Annual flows are expressed in millions of current dollars. The UNCTAD report on FDI (2005) states that the trends observed in terms of flows are compatible with those in terms of stocks.
} 
Despite a $26.5 \%$ jump in FDI flows in 2006, Africa is the continent that attracts the least FDI (3.3\% of global inward FDI and less than $10 \%$ of inward FDI to the DCs), far behind Asia, where inward investment has skyrocketed since the 1980s (see Figure 3). Africa also has the lowest score in terms of FDI flows per capita (\$33.3 per capita in 2005), far below the average for the DCs (\$61 per capita). By way of comparison, annual FDI flows per capita amount to $\$ 572.6$ in the developed countries and $\$ 119.4$ in the transition economies. Furthermore, in contrast to Asia, only a small fraction of FDI in African countries originates in Africa (3\% of the stock of FDI, as compared to 30\% in Asia).

Although Africa receives a very small share of global FDI flows, it has recorded considerable progress in volume terms. Annual FDI flows to Africa increased by a factor of 24 from 1970 to 2005, with a particularly sharp increase since the 1990s. As a percentage of GDP, inward FDI flows in 2005 accounted for $2.1 \%$ of world GDP and $3.2 \%$ of GDP in Africa.

Figure 3: Inward FDI flows

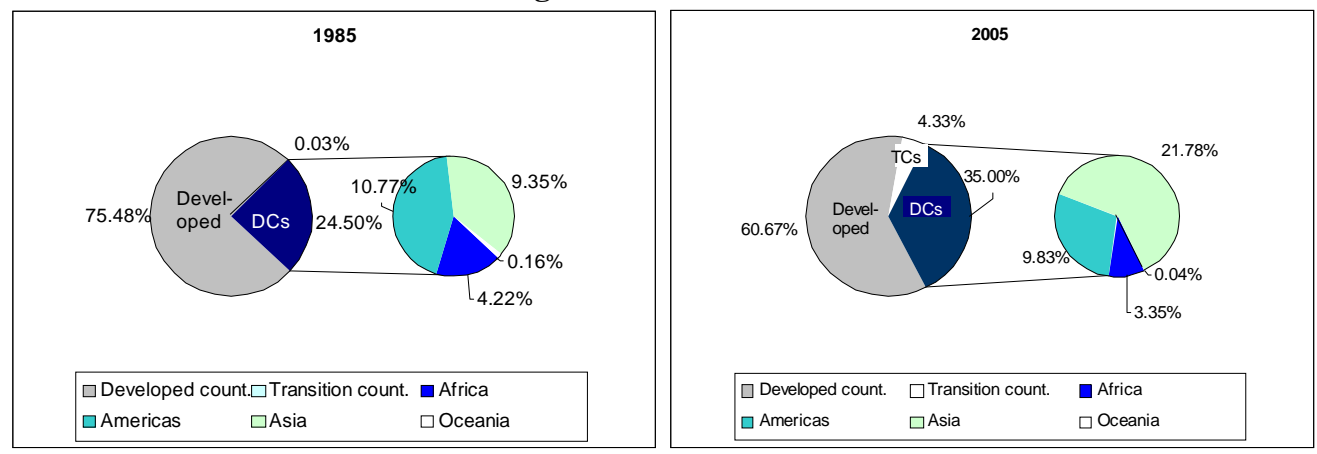

Source: UNCTAD (2006b).

In a context where the bulk of world trade is conducted by multinational firms, FDI is a means of becoming integrated into the globalisation process. It facilitates domestic employment and business creation while at the same time generating export revenue. It also offers the benefits of technology transfer: foreign investors bring with them innovative production processes, efficient organisational methods and know-how that will gradually spread throughout the country and boost its productivity. The recipient country thus gets the benefit of technical progress without having to finance it. This also gives the recipient country access to new markets. Thus, considerable gains are expected in terms of technology transfer, infrastructure development, diversification of the industrial fabric, market access and promotion of private investment. Moreover, FDI is more stable than other forms of capital inflow because it entails long-term involvement in the recipient country's economy. FDI, which by its very nature is long-term private investment, could help to reduce dependence on official aid.

From this standpoint, it would be particularly desirable for AfT to contribute towards creating an attractive environment for $\mathrm{FDI}^{8}$.

\footnotetext{
${ }^{8}$ According to the OECD (2002), the developed countries could use ODA to support investment projects involving both public and private capital.
} 


\subsection{Integration into the world trading system}

The process of accession to the WTO represents a substantial entry cost for DCs seeking to participate in international trade, and this cost is all the higher because other partners on the global scene have already imposed their rules. Considerable capacity for trade policy analysis is needed, not only for accession but also for monitoring the negotiations on a daily basis and implementing their outcomes. The formation of regional blocs also requires favourable regulation, in order to build regional production capacity as well as to form alliances, which are necessary for taking the floor at the WTO. Lastly, compliance with norms and standards constitutes a considerable barrier to the integration of DCs in international trade. In the AfT nomenclature, development projects that seek to facilitate integration into the global trading system are classified in the "trade policy and regulations" category.

Furthermore, DCs face a number of short-term costs arising from liberalisation. Aid projects addressing these costs are classified in the "trade-related adjustment" category.

\subsubsection{Trade policy and regulations}

Developing countries have inadequate capacity for trade policy analysis. They are poorly informed as to the economic and social impacts of trade agreements. In addition to this structural problem, knowledge accumulation in this field is hampered by a high rate of turnover among officials, who leave for better-paid posts (WTO, 2005). Governments often turn to international consultants for assistance in determining their strategic interests in such agreements. The studies conducted by these firms are costly and generally unsuited to the local context. As a logical consequence of their poor understanding of trade issues, DCs do not regard trade as a development tool. Their reluctance to give commitments leads them to conclude trade agreements belatedly, and the agreements are not necessarily suitable for them. This need for analytical capacity building was mentioned explicitly in the declaration that opened the Doha Round in 2001.

Analytical capacity building programmes should include efforts to teach DCs to form alliances (for example, through common analytical tools) and to encourage them to make use of the dispute settlement body.

Where mastery of trade policy and regulations is concerned, compliance with sanitary and phytosanitary standards is regarded as the main constraint on DCs' participation in international trade. The proliferation of such standards is due to the increase in global wealth and the reduction of tariff barriers, which leads countries to erect non-tariff barriers. A number of studies have been conducted to assess the losses arising from these norms and standards; the figures vary from sector to sector, but the amounts involved are considerable. FDI could help companies to acquire the capacity to meet market standards in OECD countries. Wilson and Cacho (2007), however, consider that investment may be affected by these standards.

\subsubsection{Trade-related adjustment}

Talking about the long-term gains from liberalisation amounts to asking how liberalisation would improve resource allocation. However, advances in economic analysis and the lessons of history 
have shown the limitations of such reasoning. Economists are in agreement about neither the global gains from liberalisation nor the distribution of these gains, as they take different views depending on the liberalisation scenarios considered and the modelling assumptions made (assumptions concerning production factors, such as the mobility of land and labour, assumptions used to model services, etc.). At all events, these gains, if any, are small (less than 1\% of world GDP) (see the following works from, respectively, the World Bank, CEPII and the Carnegie Endowment: Anderson et al., 2005; Fontagné and Decreux, 2006; Polaski, 2006). Moreover, even if it were proved that such gains are obtained, they do not necessarily lead to significant poverty reduction and their size will depend on the situation of each country (output structure, level of development etc.).

While there is disagreement on the overall impact of liberalisation on DCs, there is no doubt that trade liberalisation entails short-term adjustment costs for these countries. Stolper and Samuelson (1941) have shown that trade growth can have a considerable impact on income distribution; lowskilled workers, for example, have a great deal to lose. The costs of trade liberalisation and the obstacles to liberalisation that would be profitable for all are better understood today, and the losers are more clearly identified (Stiglitz and Charlton, 2005). These costs were acknowledged in September 2003 in a letter co-signed by the president of the World Bank, the managing director of the International Monetary Fund (IMF) and the director-general of the WTO. Liberalisation entails adjustment costs for both the private sector (e.g. labour markets) and the public sector (loss of tax revenue). The costs of labour market reallocation are particularly high in DCs having a large labour force. These costs are summarised in Table 1.

Table 1: Adjustment costs connected with trade liberalisation

\begin{tabular}{|c|c|c|}
\hline \multirow[t]{2}{*}{ Private sector } & Labour & $\begin{array}{l}\text { Opportunity cost of unemployed labour } \\
\text { Obsolescence of skills and country-specific forms of qualification } \\
\text { Decline in wages and salaries } \\
\text { Costs of re-qualification } \\
\text { Personal costs (e.g. mental suffering) } \\
\text { Other costs (e.g. rent-seeking behaviour) }\end{array}$ \\
\hline & Capital & $\begin{array}{l}\text { Opportunity cost of under-employed or idle capital } \\
\text { Costs of obsolete capital (capital destruction) } \\
\text { Transition costs of transferring capital from one activity to } \\
\text { another }\end{array}$ \\
\hline Public sector & \multicolumn{2}{|c|}{$\begin{array}{l}\text { Change in the tax base } \\
\text { Social protection expenditures (e.g. unemployment benefits) } \\
\text { Erosion of advantages stemming from preferential trade treatment } \\
\text { Efforts to maintain macroeconomic stability } \\
\text { Costs of implementing trade reform } \\
\text { Concerns unrelated to trade: food security, support for rural areas, environmental } \\
\text { concerns }\end{array}$} \\
\hline
\end{tabular}

Fernandez de Cordoba et al. (2005) provide a bibliography of the literature on measurement of adjustment costs. Most of the works listed concentrate on a few specific adjustments, using models developed specifically for this purpose ${ }^{9}$. The reason is that general or partial equilibrium models do not

\footnotetext{
${ }^{9}$ Models dealing specifically with the labour market estimate these losses at $12 \%$ of the gains derived from liberalisation over the five years following implementation of the trade agreement (Magee, 1972), and the duration of unemployment may be as much as 31 weeks (Bale, 1976).
} 
capture these short-term adjustment costs; rather, such models yield long-term results. Moreover, they are static, providing only a snapshot of the economy before and after the tariff shock; they are thus incapable of capturing intermediate effects on output and employment. More specifically, they do not estimate the duration of unemployment and do not always model the labour market, or lack the data needed to do so. Lastly, few of these studies examine the adjustment costs of liberalisation in DCs. Many of them are ex post, descriptive studies.

At the macroeconomic level, some countries are experiencing erosion of trade preferences ${ }^{10}$. The consequences of this vary with countries' macroeconomic situation, and more particularly with their ability to make budget transfers (and hence with their debt/GDP ratios), labour market rigidities or exchange rate regime. Taken as a whole, this literature indicates that the problem of preference erosion varies very widely from one country or sector to the next (Lippoldt and Kowalski, 2005; Alexandraki and Lankes, $2004^{11}$ ).

In sum, liberalisation will necessarily entail non-negligible adjustment costs for DCs. AfT designed to facilitate such adjustments is classified in the "trade-related adjustment" category.

\subsection{Infrastructure-related constraints on trade}

For many years, the volume and distribution of international trade were explained by reference to policy obstacles alone. In reality, however, the cost of trade is a determining factor (Limao and Venables, 2001). About half of world trade takes place between countries located less than 3000 kilometres from one another. For some DCs, transport costs can be several times higher than those of developed countries, because they are located farther from relevant import and export markets, because their infrastructure is inadequate or because they are landlocked and their neighbours have inadequate infrastructure. According to some estimates, landlocked countries face transport costs $50 \%$ higher than those of comparable economies that have a seacoast, and the doubling of transport costs reduces trade flows by approximately half.

Apart from high freight costs (which are still higher when oil prices surge and the US dollar is strong), the unpredictability of the time required for transport (due to unreliable transport services) engenders substantial costs. This unpredictability is even more of a problem for landlocked countries. According to Arvis et al. (2007), a country without an outlet to the sea will have less trade and slower growth than a maritime country, mainly as a result of these transport uncertainties. It is estimated that a delay of one day in delivery of goods is equivalent on average to a decline of over $1 \%$ in trade, or to an additional distance of $70 \mathrm{~km}$ between trade partners. The impact is such delay is greater for DCs, which generally trade in perishable products (Melitz, 2003). In practice, the price impact of unpredictability depends on the nature of the good and on the size of the supplier country (a large country will be able to influence world prices, while a small country will not). There are other

\footnotetext{
${ }^{10}$ Gradual liberalisation of markets via the reduction of customs duty rates with respect to the rest of the world (mostfavoured-nation rate of duty) has a direct impact on the level of preferential margins.

${ }^{11}$ The international financial institutions have mechanisms to finance the cost to DCs of preference erosion. For example, in April 2004 the IMF adopted a trade integration mechanism that is available to countries subjected to unforeseeable pressures on their balance of payments, such as the erosion of tariff preferences. The costs of adjustment could also be borne by the IMF's Growth and Poverty Reduction Facility (GPRF) or the Extended Financing Facility (EFF).
} 
obstacles to transport - corruption, excessive regulation, inefficiency of the private sector and so on but they are less important than the unreliability and unpredictability of transport services.

Access to world markets thus depends as well, and indeed primarily, on physical constraints such as the availability of trade corridors and transport systems. This is the issue of trade-related infrastructure. According to the model developed by Djankov et al. (2006), cutting the factory-to-ship transport time from 48 days to 10 would increase sub-Saharan Africa's exports by $10 \%$. At the global level, improvements in port efficiency and customs regimes, as well as rationalised and/or harmonised regulatory policy, can be highly beneficial for trade. International coordination is essential in order to avoid under-investment in transport infrastructure. Advances in port efficiency, regulatory systems and international transport infrastructure bring a relatively greater increase in exports than in imports (Wilson et al., 2004).

The AfT category "trade-related infrastructure" covers all activities relating to goods transport, communications and energy.

\subsection{The AfT nomenclature}

To deal with these trade barriers, the Task Force on Aid for Trade ${ }^{12}$ appointed by the WTO to "operationalise" AfT proposed a broad definition of this form of aid in July 2006 (see Appendix 1), comprising:

- The AfT categories that cover traditional forms of aid, including technical assistance and trade capacity building, are trade policy and regulations and trade development. In the commitments given by WTO members after the 2005 Hong Kong conference, AfT was limited to these two categories. Similarly, they are the only two categories covered by the joint WTO/OECD Trade Capacity Building Database $\left(\mathrm{TCBDB}^{13}\right)$, created for the obligatory monitoring of WTO members' AfT contributions.

- Recognition of four other categories is in progress: trade-related infrastructure, building productive capacity, trade-related adjustment and other trade-related needs.

\footnotetext{
${ }^{12}$ At the December 2005 interministerial conference in Hong Kong, the WTO set up a Task Force on Aid for Trade to produce reports and recommendations on the possible configuration of an effective AfT mechanism, with a view to making such aid operational. The membership of the Task Force was announced on 8 February 2006: Barbados, Brazil, Canada, China, Colombia, the European Union, India, Japan, Thailand, the United States and the coordinators of the ACP Group, the African Group and the LDC Group. The Task Force is chaired by the Permanent Representative of Sweden to the WTO, Ambassador Mia Horn af Rantzien, in her personal capacity.

${ }^{13} \mathrm{http}: / /$ tcbdb.wto.org, http://oecd.org/dac/trade.
} 


\section{The lack of an AfT strategy}

\subsection{Analysis of aid for trade at global level}

\subsubsection{A confused tangle of AfT programmes}

Many different contributors are involved in providing AfT. Bilateral and multilateral donors finance projects, as well as contributing to trust funds used to conduct joint projects. Appendix 2 lists the specific contributions of certain AfT donors. Considering the number of parties involved, the WTO member countries recognised in the Doha Declaration that there was an urgent need for effective coordination of the actions of multilateral and bilateral donors, and for more assured, predictable financing of AfT.

More specifically, to help LDCs incorporate trade issues in their national development plans and poverty reduction strategy papers, an Integrated Framework of Trade-Related Technical Assistance for LDCs was created in 1997, in the wake of the action plan for the LDCs. This framework is used to provide trade-related technical assistance in accordance with the needs identified by the countries themselves (LDCs only). The Integrated Framework comprises six multilateral institutions (World Bank, IMF, UNCTAD, WTO, UNDP, International Trade Centre) and 17 contributors ${ }^{14}$.

\subsubsection{Analysis of aid for trade in 2006}

The joint WTO/OECD report on trade capacity building (WTO/OECD, 2006) is an analysis of the TCBDB database, which tracks AfT activities. It is currently based on the three main categories of AfT: trade policy and regulations, trade development and infrastructure. Their joint contribution to total AfT rose gradually from $\$ 11$ billion in 2001 to $\$ 18$ billion in 2004 , falling back to $\$ 15.5$ billion in current dollars in 2005. On average, the breakdown among these categories is as follows: $6 \%$ for trade policy and regulations, $13 \%$ for trade development and $81 \%$ for infrastructure. It should be noted, however, that this breakdown by funding amounts provides no indication as to the relative effectiveness of the categories; for example, the sums committed to infrastructure projects are vastly greater than those provided for training in trade negotiation, but do not necessarily signify greater efficiency.

Contributions are increasingly provided by bilateral donors, which made $69 \%$ of total contributions in 2005, primarily for trade development (64\%) and infrastructure (72\%) (see Appendix 2 ). Only the "trade policy and regulations" category is primarily multilateral. Lastly, the trust funds have been growing steadily since 2001 .

Africa is the main beneficiary region, receiving one-third of total contributions. Allocations to Africa are rising, mainly directed to sub-Saharan Africa. Asia receives large contributions for infrastructure $(50 \%$ of the total).

\footnotetext{
${ }^{14}$ Belgium, Canada, Denmark, Finland, France, Ireland, Italy, Japan, Netherlands, Norway, Sweden, Switzerland, United Kingdom, United States, World Bank, European Commission, UNDP.
} 
Figure 4: The three main AfT categories, by continent (millions of constant 2004 US\$)

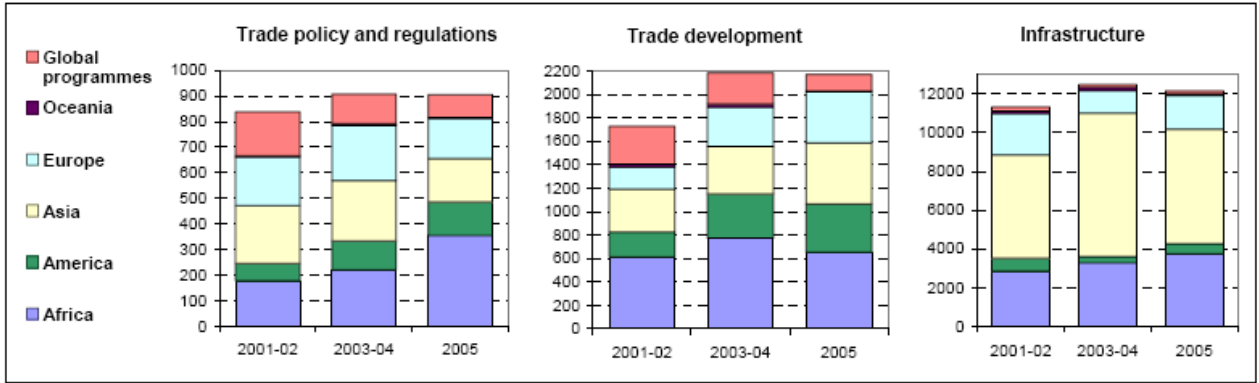

Source: WTO/OECD (2006).

As can be seen in Figure 5, the lower middle-income countries (LMICs) are the largest beneficiaries (49\% of total contributions in 2005). However, the LDCs receive many contributions through regional programmes and trust funds.

Figure 5: The three main AfT categories, by beneficiary countries group (millions of constant 2004 US\$)

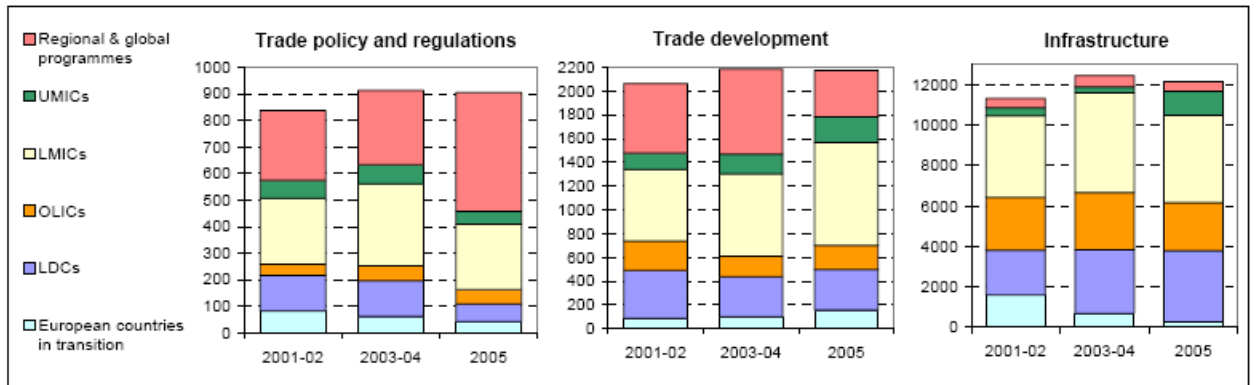

Source: $\mathrm{WTO} / \mathrm{OECD}(2006)$.

Note:

LDCs: Least developed countries. The 50 countries designated by the United Nations as least developed on the basis of levels of income, economic diversification and social development.

OLICs: Other low-income countries. This category comprises all countries not classed as LDCs but having gross national income per capita of less than $\$ 825$ in 2004 (World Bank Atlas basis).

LMICs: Lower middle-income countries. All countries having gross national income per capita between $\$ 826$ and $\$ 3,255$ in 2004.

UMICs: Upper middle-income countries. All countries having gross national income per capita between $\$ 3,256$ and $\$ 10,065$ in 2004

It is difficult to identify strategic factors at global level. The amounts fluctuate from year to year and from one country to another. Despite the progress made at the international level with the TCBDB, coordination among donors is still weak. The aid provided by multilateral and bilateral donors is rendered less effective by a general lack of strategic planning. Donors' actions remain relatively uncoordinated operations undertaken as the opportunity arises. As for the Integrated Framework, it proved inadequate, leading to the launch of an "Enhanced Integrated Framework" in 2007. 


\subsection{The need for donors to define a strategy}

The absence of a strategic framework for the granting of AfT is probably due to the risks that such programmes entail for donors. Solignac Lecomte (2001) identifies various risk factors associated with AfT programmes:

- Negative discrimination: donors may be reluctant to undertake capacity building in areas where they perceive the beneficiaries' interests as being contrary to their own (e.g. creating or strengthening capacity to contest anti-dumping measures taken by other countries).

- Positive discrimination: donors may prefer to generate benefits for their own economies or firms rather than undertake operations that would primarily benefit receiving countries.

- Tied aid: most of the profits go to suppliers of capital goods and technical assistance. Many donorsponsored activities are presented - and in some cases rightly so - as development aid, but often the bulk of the budget, which can be large, is pocketed by donor-country suppliers, NGOs and consultants, with no real guarantee that they are the most efficient suppliers or that the project itself really addresses a development priority. In practice, tied aid takes the form of projects that include a considerable amount of technical assistance from the donor country.

Nevertheless, donors are now obliged to develop a strategy, because AfT, now officially a component of ODA, must adhere to the goals set forth in the Paris Declaration: ownership, harmonisation, alignment, results and mutual responsibility. The reports on trade published in 2005 by UNCTAD and the UK's Commission for Africa and the conclusions of the G8 Gleneagles summit all mention the need for increased support for trade capacity building. Many policy statements have been issued to announce an increase in AfT: the European Union confirmed the importance of AfT by announcing that its aid would increase to $€ 2$ billion a year by 2010 ; the United States has promised to double its annual funding to $\$ 2.7$ billion by 2010 ; and Japan has announced it will contribute $\$ 10$ billion over three years.

In June 2007, at the G8 Heiligendamm summit, the assembled heads of state also recommended that this increased aid be directed towards creating a favourable environment for FDI, and this call has been echoed by UNCTAD and the OECD. The search for effective methods of increasing FDI in DCs is expected to a key issue at the 12th session of the Accra Conference in April 2008. In view of all this, it has become indispensable to develop a strategic framework as a guide for the allocation of AfT resources ${ }^{15}$.

\section{Outline of a strategic approach to aid for trade}

\subsection{Strategic framework}

Donors should set their AfT priorities according to:

- the AfT needs of beneficiary countries. These needs could be identified through a typology such as the one presented in the next sub-section. This should improve partnerships

\footnotetext{
${ }^{15}$ The WTO and OECD have jointly drafted a questionnaire to study existing strategies in this respect and provide strategic guidelines for the formulation of such a strategic framework.
} 
between donors and developing countries, what is considered as a key factor to progress on aid effectiveness (in the Declaration of Paris in 2005 as well as in the Accra Agenda for Action in $2008^{16}$ ).

- the activities of other donors and the comparative advantages of each donor. These advantages stem from the specific features of each donor: funding allocated, expertise, priority area of operations, etc.;

- a comparison between the needs of beneficiaries and the existing or potential supply of aid. This would make it possible to draw up strategic frameworks classifying the operations of each donor by mode of aid delivery (AfT categories, operating procedures etc.) and by country or region. A higher dialogue on development policies has to be engage to select appropriated aid programs. This would allow to strengthen country ownership over development which is one of the weaknesses underlined in Accra. Also, this could help to reduce the fragmentation of aid by improving the complementarity of donors'efforts and the division of labour among donors, including allocation of resources within sectors, within countries and across countries (Accra, 2008).

\subsection{Typology of current and future AfT needs}

To develop a strategy on the supply side, it is essential to pinpoint the specific demand of each country in terms of aid for trade, but this is easier said than done. Consider the example of the Integrated Framework, which was supposed to centralise the AfT needs of LDCs, and on this basis to provide a tool to make the AfT of the various donors more effective. The IF has met with great difficulties and has not succeeded in this goal, as witness the fact that trade is still insufficiently integrated into national development plans.

This paper therefore undertakes to develop a typology of the trade needs of certain countries. It is a new typology, and is in keeping with current research aimed at identifying countries' trade-related needs. In particular, the International Trade Centre is conducting research on indicators that will reflect the trade needs of all countries, which will make it possible to develop typologies for multiple study areas. For our present purposes, the "study area" selected consists of the countries to which the Agence Française de Développement provides AfT, and the typology itself draws on existing indicators that seemed particularly relevant to the AFD's practices.

\subsubsection{Method}

To pinpoint individual countries' trade-related needs, we selected a number of indicators relating to the categories used in the AfT nomenclature. This tool has certain statistical limitations, however, owing to problems of data availability and reliability. Thus, the typology presented here cannot by itself serve as the foundation for an AfT strategy, but it does allow us to identify priorities for action.

\footnotetext{
${ }^{16}$ See the official website of the Accra Agenda: http://www.accrahlf.net/.
} 


\section{a. Choice of study area}

Owing to data availability constraints, this typology covers 50 countries ${ }^{17}$ belonging to the Priority Solidarity Zone of French development co-operation ${ }^{18}$. Its results can be analysed at either the country or the regional level (see Appendix 3). The regions considered here are the economic regions concerned by free trade agreements with the European Union: North African countries via the Barcelona process; for other African countries, the regions concerned by the negotiations on Economic Partnership Agreements; and the ASEAN and Caribbean regions.

The aim of the typology is to establish a ranking of the trade-related needs of these countries in order of importance. This ranking is constructed solely on the basis of this panel of countries; this does not mean that the best-integrated countries appearing on this list (hence those that require the least aid) do not need AfT, but they take lower priority in terms of aid allocation.

\section{b. Scoring method}

For each variable selected, countries receive scores of 1,2, 3 or 4; a score of 1 is assigned to countries most in need of AfT in regard to the variable considered, and a score of 4 to those least in need. The panel of countries is thus divided into quartiles based on their scores for each variable ${ }^{19}$.

\section{c. Choice of variables}

It is no easy matter to establish indicators such that each clearly reflects one category of the AfT nomenclature, since these categories straddle common themes. It is thus simpler and more to the point to consider the three main objectives of AfT (see Table 2): support for trade-oriented production (which covers the AfT categories "trade development" and "building productive capacity"), support for integration into the world trading system (covering "trade policy and regulations" and "trade-related adjustment") and strengthening trade-related infrastructure. We focused on these three objectives, since if DCs are to become integrated into international trade, they must produce, must have access to the world market and must be able to transport their goods and services. Our analysis thus considers the five main categories of $\mathrm{AfT}^{20}$ from this point of view.

\footnotetext{
${ }^{17}$ Algeria, Angola, Benin, Burkina Faso, Burundi, Cambodia, Cameroon, Cape Verde, Central African Republic, Chad, Comoros, Congo Rep. (Brazzaville), Côte d'Ivoire, Democratic Republic of Congo, Dominican Republic, Equatorial Guinea, Eritrea, Ethiopia, Gabon, Gambia, Ghana, Guinea, Guinea-Bissau, Haiti, Kenya, Laos, Lebanon, Liberia, Madagascar, Mali, Morocco, Mauritania, Mozambique, Namibia, Niger, Nigeria, Rwanda, Sao Tome and Principe, Senegal, Sierra Leone, South Africa, Sudan, Suriname, Tanzania, Togo, Tunisia, Uganda, Viet Nam, Yemen, Zimbabwe.

${ }^{18}$ The Priority Solidarity Zone is a list of countries for which the French government considers that ODA can have a particularly useful impact on the development of institutions, society and the economy. The government drew up this list in 1998.

${ }^{19}$ The interval between the maximum and minimum values of the variable (for our sample of countries) is divided into four equal parts.

${ }^{20}$ The category "other trade-related needs" is excluded, as this category has been only sketchily described and has no specific objective.
} 
Table 2: Indicators selected for the various AfT objectives and categories

\begin{tabular}{|c|c|c|}
\hline $\begin{array}{c}\text { Category in the AfT } \\
\text { nomenclature }\end{array}$ & AfT objective & Indicators selected \\
\hline Trade development & \multirow{2}{*}{$\begin{array}{l}\text { Support for trade-oriented } \\
\text { production }\end{array}$} & \multirow{2}{*}{$\begin{array}{ll}\text { - } & \text { trade balance } \\
\text { - } & \text { population growth } \\
\text { - } & \text { export concentration index } \\
\text { - } & \text { time required to start a business }\end{array}$} \\
\hline $\begin{array}{l}\text { Building productive } \\
\text { capacity }\end{array}$ & & \\
\hline $\begin{array}{l}\text { Trade policy and } \\
\text { regulations }\end{array}$ & $\begin{array}{l}\text { Support for integration } \\
\text { into the world trading } \\
\text { system }\end{array}$ & $\begin{array}{ll}\text { - } & \text { evaluation of the need for training in trade } \\
\text { - } & \text { negotiations } \\
\text { - } & \text { geogre of intra-regional trade } \\
\text { - } & \text { geographical diversification of imports } \\
\text { - } & \text { share of customs revenue in government } \\
& \text { revenue }\end{array}$ \\
\hline $\begin{array}{l}\text { Trade-related } \\
\text { infrastructure }\end{array}$ & $\begin{array}{l}\text { Strengthening trade- } \\
\text { related infrastructure }\end{array}$ & $\begin{array}{l}\text { - } \quad \text { time required for export } \\
\text { - } \quad \text { cost of exporting }\end{array}$ \\
\hline
\end{tabular}

The variables used, whether qualitative or quantitative (in the latter case, we use the average of the last three available years, namely 2002, 2003 and 2004), were selected with an eye to statistical availability.

\section{* Support for trade-oriented production}

Several variables were selected for the analysis of support for trade-oriented production:

- The trade balance is the difference between exports and imports of goods and services (as a percentage of GDP). We assign a score of 1 to countries with a poor trade balance, as this attests to the difficulty they experience in producing and exporting enough to pay for the imports they need. This score indicates a need to build productive or freight capacity, and implies a tendency to indebtedness that is incompatible with development. The countries in the sample all run a trade deficit except South Africa (which exports minerals) and the oil-producing countries (Nigeria, Angola, Côte d'Ivoire, Algeria, Gabon, Congo).

Figure 6: Trade balance of the countries in the panel (\% of GDP) 


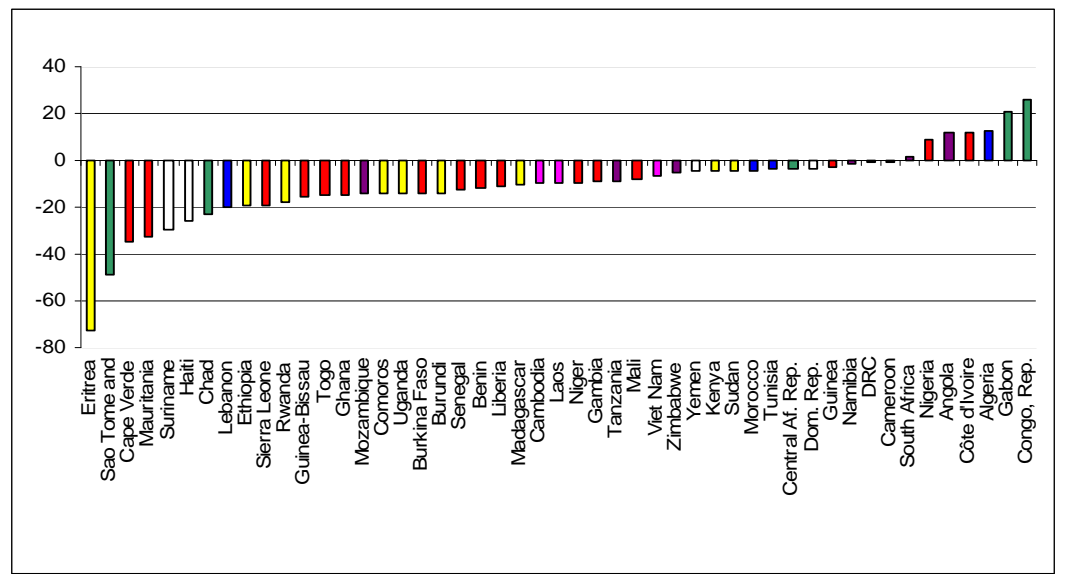

Source: WDI.

Note: The regions are represented by colours: blue for North Africa, green for Central Africa, red for West Africa, yellow for East Africa, violet for Southern Africa and pink for ASEAN. All other countries are grouped in the "other" category (in white).

- The population growth indicator used is the estimated population growth rate from 2006 to $2050^{21}$. It reflects future needs in terms of local supply. A score of 1 is assigned to countries experiencing explosive population growth (notably Mali and Niger). In South Africa, in contrast, the population is projected to shrink, as its upward trend has been reversed by the HIV/AIDS epidemic.

Figure 7: Estimated rate of population growth, 2006-50

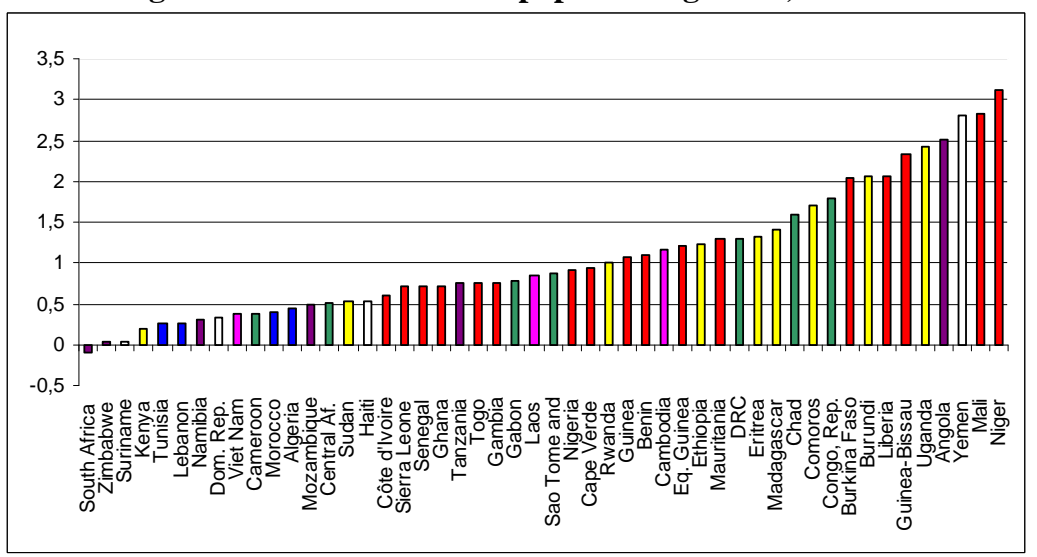

Source: FAO.

Note: The regions are represented by colours: blue for North Africa, green for Central Africa, red for West Africa, yellow for East Africa, violet for Southern Africa and pink for ASEAN. All other countries are grouped in the "other" category (in white).

\footnotetext{
${ }^{21}$ The formula used is (pop 2050 - pop 2006) / pop 2006, where pop is the number of inhabitants (census data for 2006 and FAO forecasts for 2050).
} 
- The export concentration index indicates the diversification of the products exported ${ }^{22}$. An index close to 1 (which will be scored 1) indicates that exports are very highly concentrated, i.e. that only one or a few products are exported. A value close to 0 (which will be scored 4) indicates more diversified trade.

The results are quite varied across the panel of countries. Cambodia and South Africa receive the best scores, whereas the exports of many African countries are based on a rather low number of products. This index reveals countries' dependence on certain markets, and in particular highlights the case of the oil-producing countries (Angola, Guinea, Gabon, Nigeria etc.).

Figure 8: Export concentration index

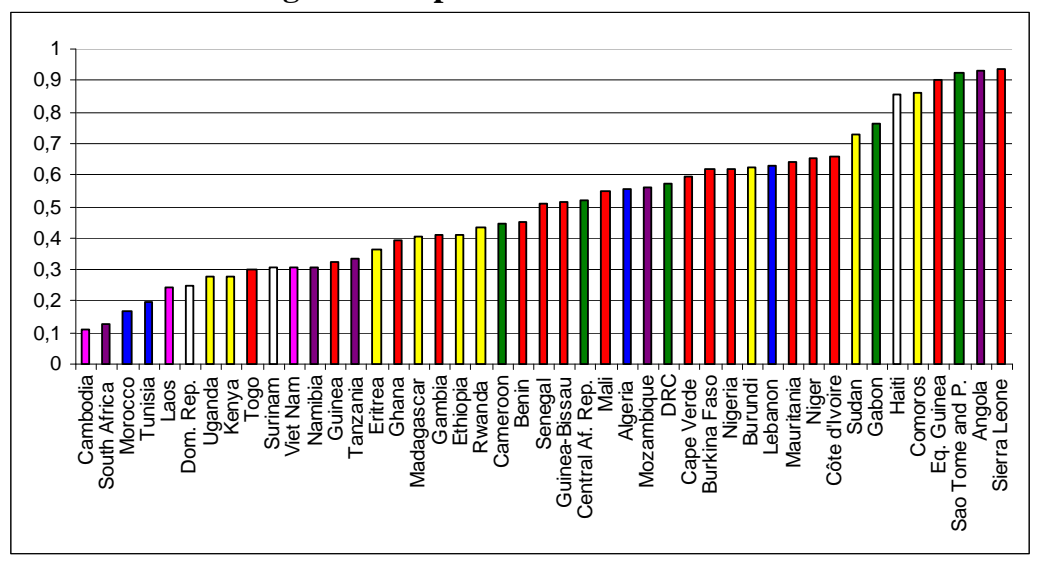

Source: UNCTAD (2005).

Note: The regions are represented by colours: blue for North Africa, green for Central Africa, red for West Africa, yellow for East Africa, violet for Southern Africa and pink for ASEAN. All other countries are grouped in the "other" category (in white).

- The time required to start a business ${ }^{23}$ indicates the extent of the bureaucratic constraints that can affect activities related to the country's international trade (production, processing, freight etc.). A score of 1 is assigned to those countries where the most time is required to start a business. For

22 It is calculated on the same basis as the Herfindahl-Hirschmann index, according to the following formula: $H_{i}=\frac{\sqrt{\sum_{i=1}^{n}\left(\frac{x_{i}}{X}\right)^{2}}-\sqrt{1 / n}}{1-\sqrt{1 / n}}$

where $H_{j}=$ index value for the country, $x_{i}=$ value of exports of produit $i$, and $n=$ number of product groups (from the Standard International Trade Classification, revision 3, at the three-digit level).

\footnotetext{
${ }^{23}$ The time required to start a business is recorded in days. This figure, provided by incorporation lawyers, indicates the median time required to carry out the whole procedure, which is considered to be completed once the company has received all the documents involved, such as certificates or tax registration. If a part of the procedure can be accomplished more quickly at an additional cost, then the quickest method is chosen. The time that the entrepreneur spends collecting information is not counted. It is assumed that the entrepreneur knows all the rules at the outset and knows in what order the various steps must be carried out, but has not yet had any contacts with government officials.
} 
over half the countries in the panel, it takes less than two months to deal with these administrative formalities; for the others, a good deal more time is required - up to 694 days in Suriname and 233 days in Guinea-Bissau.

Figure 9: Time required to start a business (days)

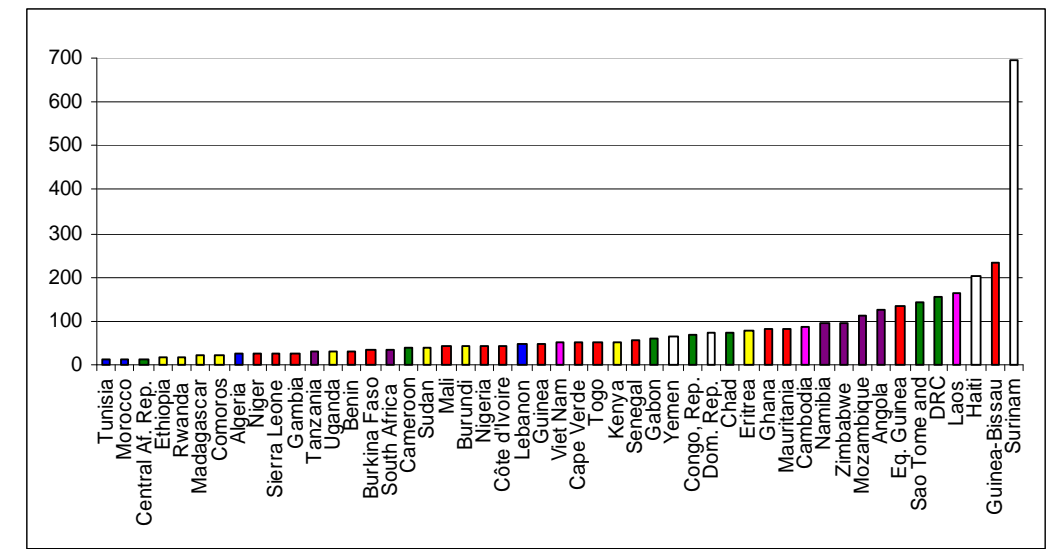

Source: World Bank, Doing Business 2006.

Note: The regions are represented by colours: blue for North Africa, green for Central Africa, red for West Africa, yellow for East Africa, violet for Southern Africa and pink for ASEAN. All other countries are grouped in the "other" category (in white).

\section{* Support for integration into the world trading system}

Where support for integration into the world trading system is concerned, the following variables are studied:

- The need for training in trade negotiations was evaluated on the basis of the experience of four experts from the UN Economic Commission for Africa. They were asked to rank the countries on the list by their level of need for further knowledge in the field of trade negotiations and regulations, assigning a score of 1 to those in greatest need and a score of 4 to those least in need. The countries of sub-Saharan Africa are particularly in need of training in trade negotiations. 
Figure 10: Need for training in trade negotiations (scored on a scale from 1 to 4)

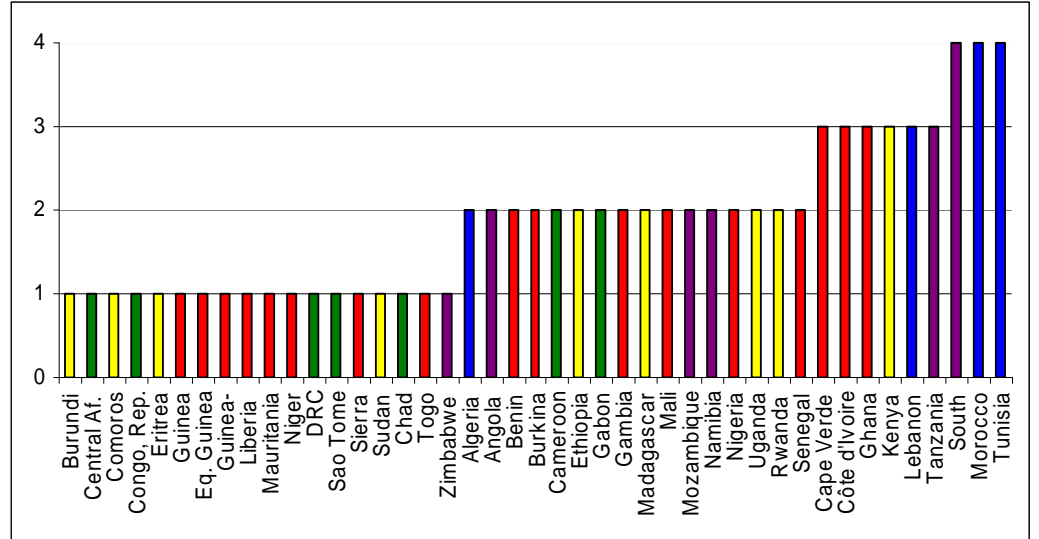

Source: UN Economic Commission for Africa.

Note: The regions are represented by colours: blue for North Africa, green for Central Africa, red for West Africa, yellow for East Africa, violet for Southern Africa and pink for ASEAN. All other countries are grouped in the "other" category (in white).

- To evaluate regional integration, several indicators may be used: the share of intra-regional trade and indicators of the geographical diversification of trade partners.

$\rightarrow$ The share of intra-regional trade in a country's total external trade (exports plus imports) ${ }^{24}$ is calculated on the basis of the regions selected ${ }^{25}$. Countries whose regional exports account for only a small share of total exports receive a score of 1. Namibia, Zimbabwe and Burkina Faso seem to be actively involved in regional trade. On the whole, however, the countries covered in this study are not strongly oriented towards such trade.

\footnotetext{
${ }^{24}$ The formula is as follows: regional (exports + imports) / total (exports + imports).

${ }^{25}$ See Appendix 3, "Economic regions used in the typology".
} 
Figure 11: Share of intra-regional trade in total trade $(\%)$

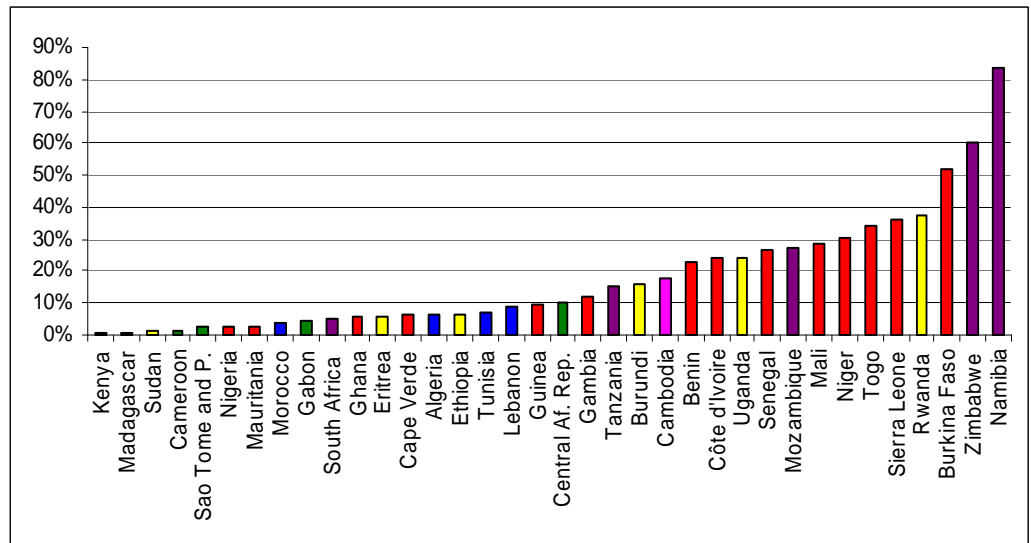

Source: COMTRADE.

Note: The regions are represented by colours: blue for North Africa, green for Central Africa, red for West Africa, yellow for East Africa, violet for Southern Africa and pink for ASEAN. All other countries are grouped in the "other" category (in white).

$\rightarrow$ The two indicators of geographical diversification show each country's trade with its three main trading partners as a percentage of its total trade. Separate indicators are calculated for imports and exports. The higher the percentage, the more dependent the country is on the economic (and political) situation of a few partners (this is true for imports as well as exports). For the countries studied here, these indicators of geographical diversification lie between $30 \%$ and $90 \%$, with a mean of $43 \%$ for imports and $55 \%$ for exports. This means that these countries have more import partners than export partners. Ghana and Kenya are found to be the most geographically diversified when both imports and exports are considered. Countries whose trade shows little geographical diversification include Sao Tome and Principe, undoubtedly because this is an island state; countries with abundant natural resources, such as Sierra Leone and Gabon; and countries whose neighbours have more developed economies, such as Namibia (close to South Africa). 
Figure 12: Geographical diversification (as \% of imports)

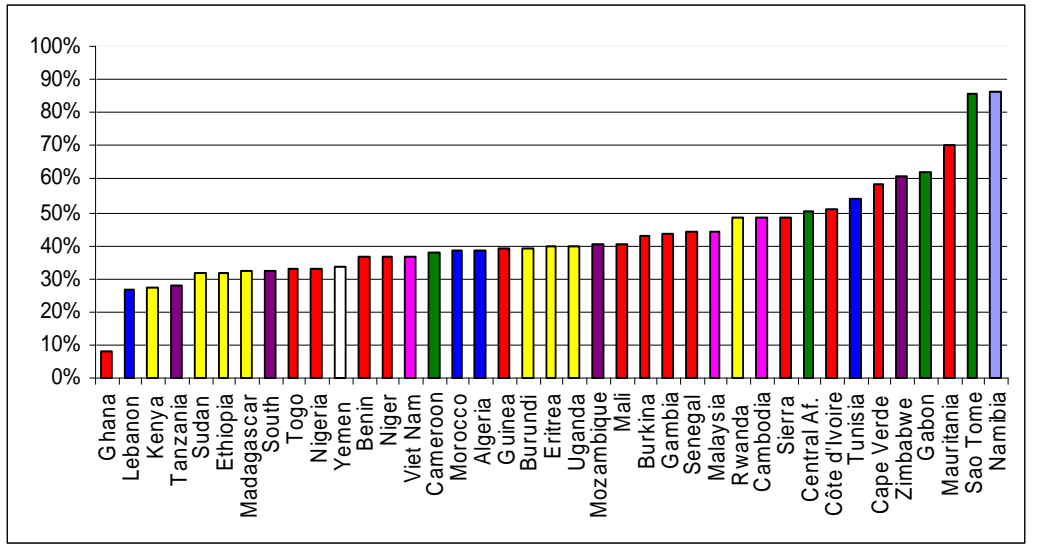

Source: COMTRADE.

Note: The regions are represented by colours: blue for North Africa, green for Central Africa, red for West Africa, yellow for East Africa, violet for Southern Africa and pink for ASEAN. All other countries are grouped in the "other" category (in white).

Figure 13: Geographical diversification (as \% of exports)

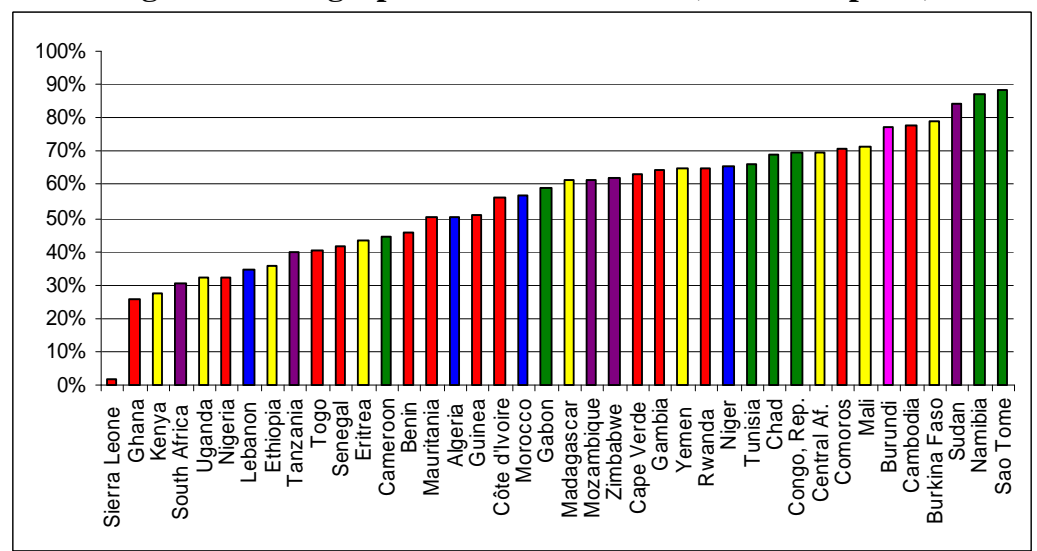

Source: COMTRADE.

Note: The regions are represented by colours: blue for North Africa, green for Central Africa, red for West Africa, yellow for East Africa, violet for Southern Africa and pink for ASEAN. All other countries are grouped in the "other" category (in white).

- The share of customs revenue in government revenue is the share estimated by the World Bank, taking account of all receipts in local currency. The score of 1 is assigned to countries where this share is high, as these countries will need substantial aid to meet the costs of adjustment to the liberalisation process. These costs will be all the higher for countries whose exports show little diversification. Some countries are extremely dependent on customs revenue: it accounts for over $50 \%$ 
of the GDP of Gambia, Niger and the Comoros, and exceeds 30\% of GDP in many West African and East African countries.

Figure 14: Share of customs revenue in government revenue (\% of GDP)

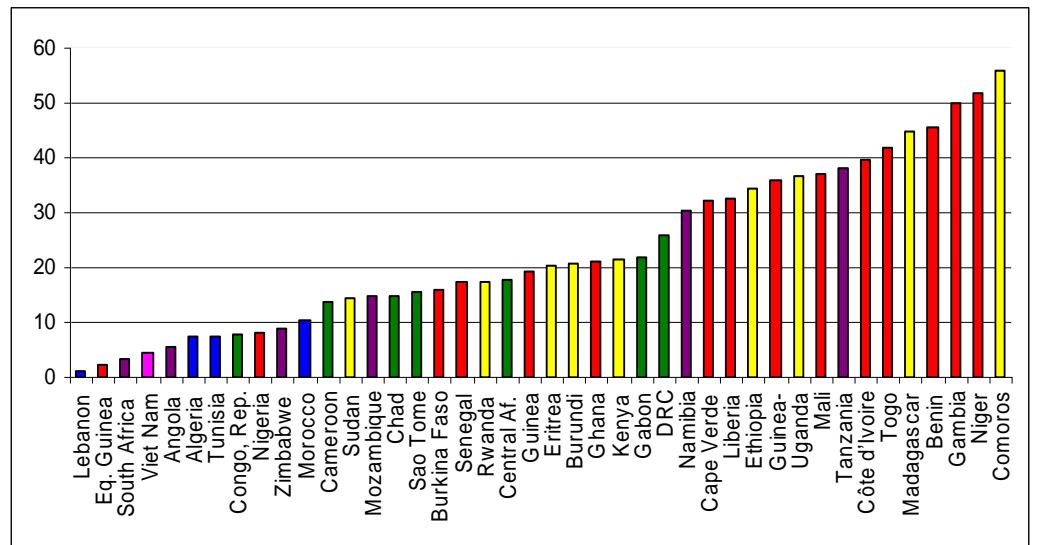

Source: WDI.

Note: The regions are represented by colours: blue for North Africa, green for Central Africa, red for West Africa, yellow for East Africa, violet for Southern Africa and pink for ASEAN. All other countries are grouped in the "other" category (in white).

\section{* Strengthening trade-related infrastructure}

Where infrastructure needs are concerned, two variables were selected: the time required for export (in days), from the outset of the procedure to its completion ${ }^{26}$, and the cost of exporting (importing involves roughly the same time and costs as exporting). For countries such as Rwanda, Burundi and Zimbabwe, which face both high costs and a long period of time for exporting, the lack of appropriate infrastructure for goods transport is clearly a major obstacle to trade development.

\footnotetext{
${ }^{26}$ It is assumed that neither the exporter nor the importer wastes time and that each party endeavours to carry out each remaining step without delay. If a procedure can be accomplished more quickly at an additional cost, the quickest legal procedure was chosen. Waiting time between steps (e.g. while the cargo is being unloaded) is included. The cost of exporting comprises all expenses incurred in carrying out the procedures needed to export or import intermediate goods, including administrative costs, customs clearance, costs associated with technical orders, terminal service and handling charges, and domestic transport. It does not, however, include tariffs or local business tax.
} 
Figure 15: Time required for exporting (days)

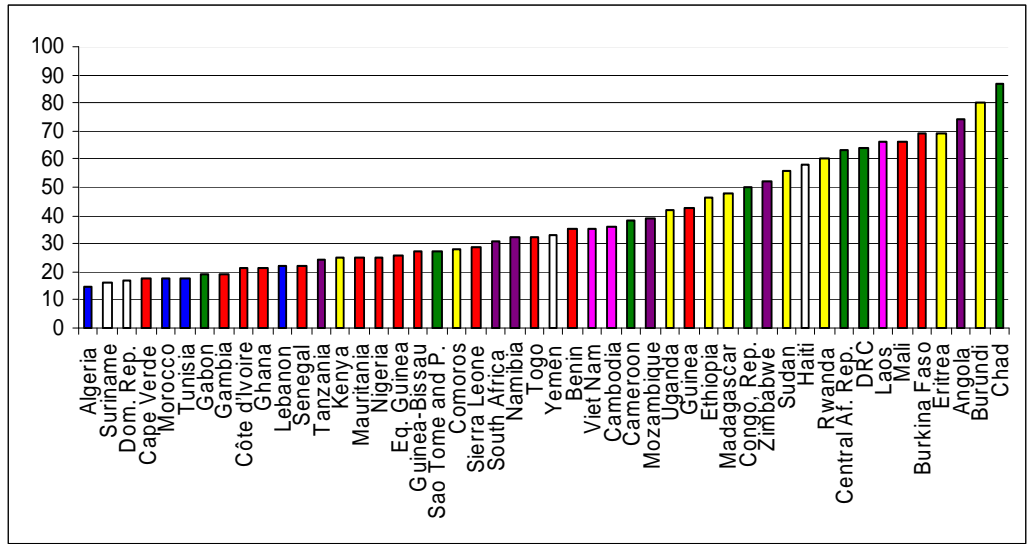

Source: World Bank, Doing Business 2006.

Note: The regions are represented by colours: blue for North Africa, green for Central Africa, red for West Africa, yellow for East Africa, violet for Southern Africa and pink for ASEAN. All other countries are grouped in the "other" category (in white).

Figure 16: Cost of exporting (US\$/container)

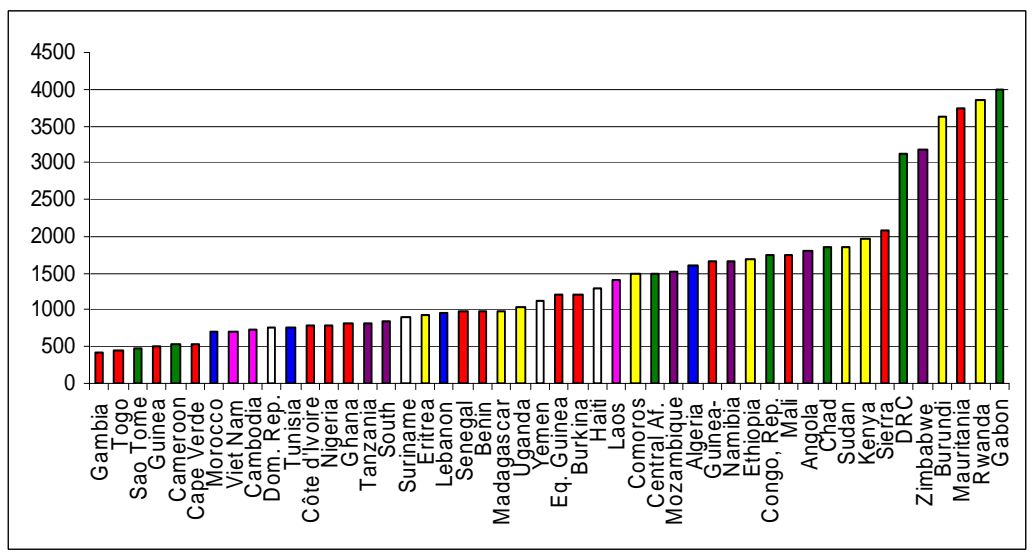

Source: World Bank, Doing Business 2006

Note: The regions are represented by colours: blue for North Africa, green for Central Africa, red for West Africa, yellow for East Africa, violet for Southern Africa and pink for ASEAN. All other countries are grouped in the "other" category (in white). 


\subsubsection{Regional disparities in AfT needs}

a. Overall results

Figures 17 and 18 encapsulate all of the results. For each country, the scores are reported for each AfT objective: "Support for trade-oriented production", "Strengthening trade-related infrastructure" and "Support for integration into international trade". The values for each country were calculated by taking the average of the scores for the variables in each category. Remember that a score of 1 is assigned to the countries most in need of AfT and a score of 4 to those least in need.

Figure 17: Countries' needs in terms of support for trade-oriented production and strengthening trade-related infrastructure

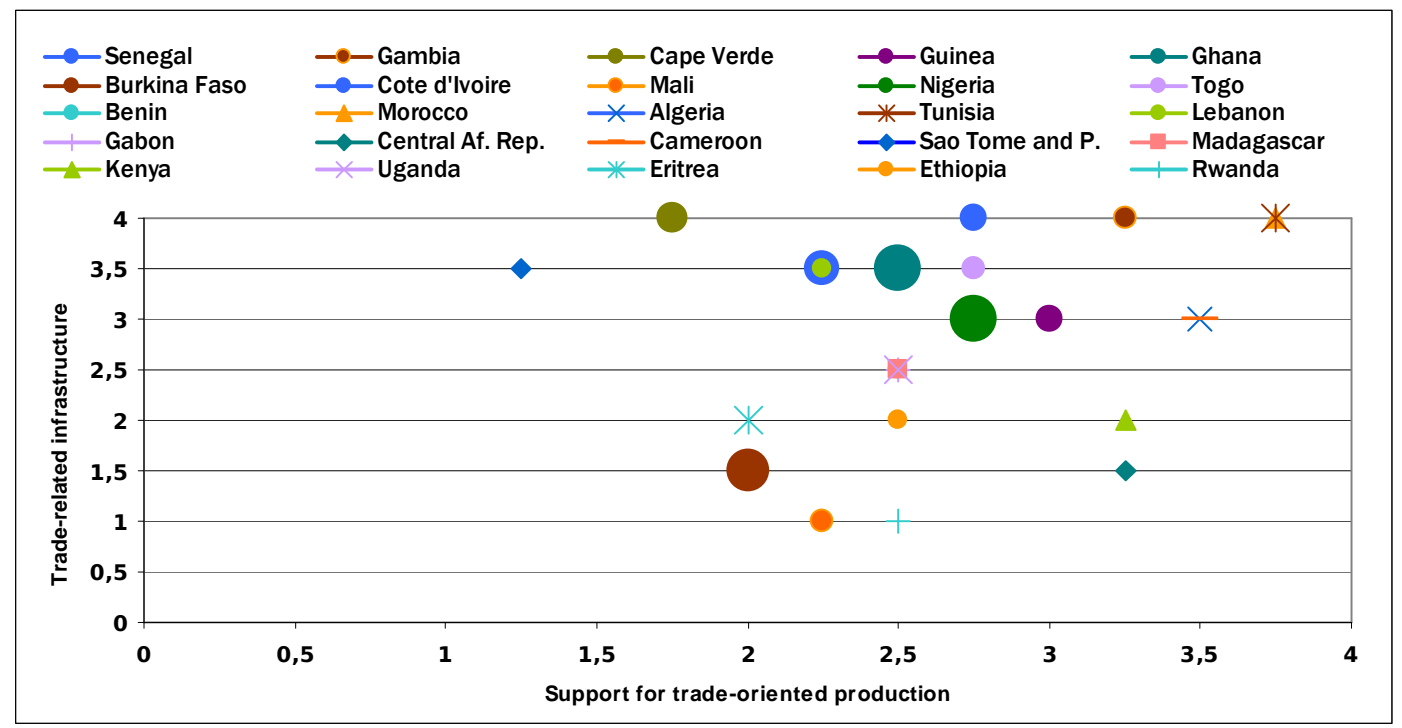

Source: Authors' calculations. 


\section{Figure 18: Countries' needs in terms of support for trade-oriented production and support for}

integration into international trade

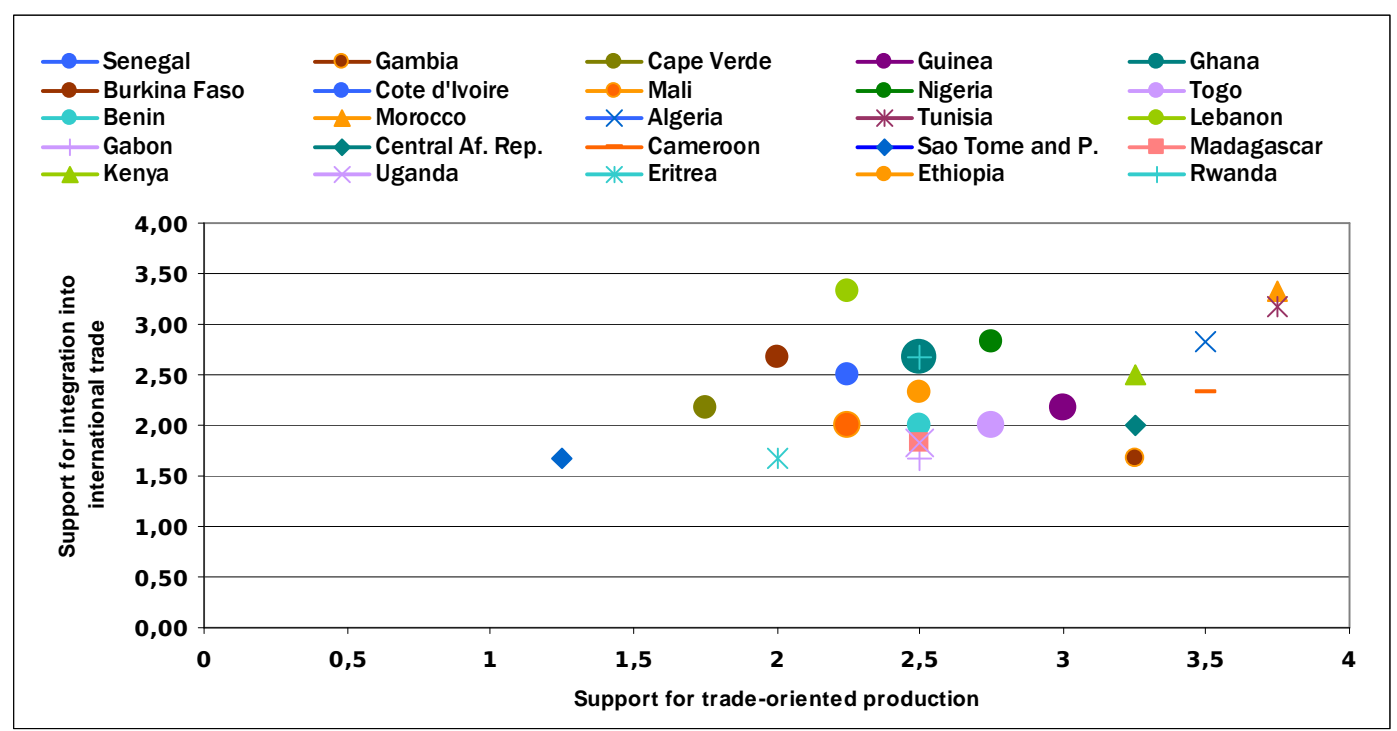

Source: Authors' calculations.

Detailed results by country are presented in Appendix 4. Here, we will examine more closely the AfT needs of each region.

\section{b. Results by region}

For the region-by-region analysis, we opted for a three-dimensional graphical representation. The need for support for trade-oriented production is represented on the x-axis, and trade-related infrastructure needs on the y-axis. The size of the dots is proportional to countries' need for support for integration into international markets: the larger the dot, the greater the need for training in trade negotiations or for help in diversifying their economies, becoming integrated into the regional market or absorbing the costs of adjustment to liberalisation.

The region of West Africa is made up of countries with highly varied needs; it is also the region containing the largest number of countries. According to Figure 19, some of them need special attention, particularly Burkina Faso and Mali. The rapid growth of Burkina Faso's population means that its future needs will be considerable, and the time required for export from the country is too long. Mali displays the same characteristics. In addition, Mali's export system shows very little diversification. Unless proper tax reforms are undertaken, the country could suffer from substantial adjustment costs, given the high proportion of customs tax revenue in total government revenue. Benin will also face high adjustment costs. Sierra Leone (not presented here owing to lack of data) is a priority country in terms of aid for trade: its production system is strongly geared towards diamond and gold mining, its need for training in trade matters is considerable, as is the cost of exporting, and its imports come from a poorly diversified set of trade partners. 
Figure 19: AfT needs of West African countries

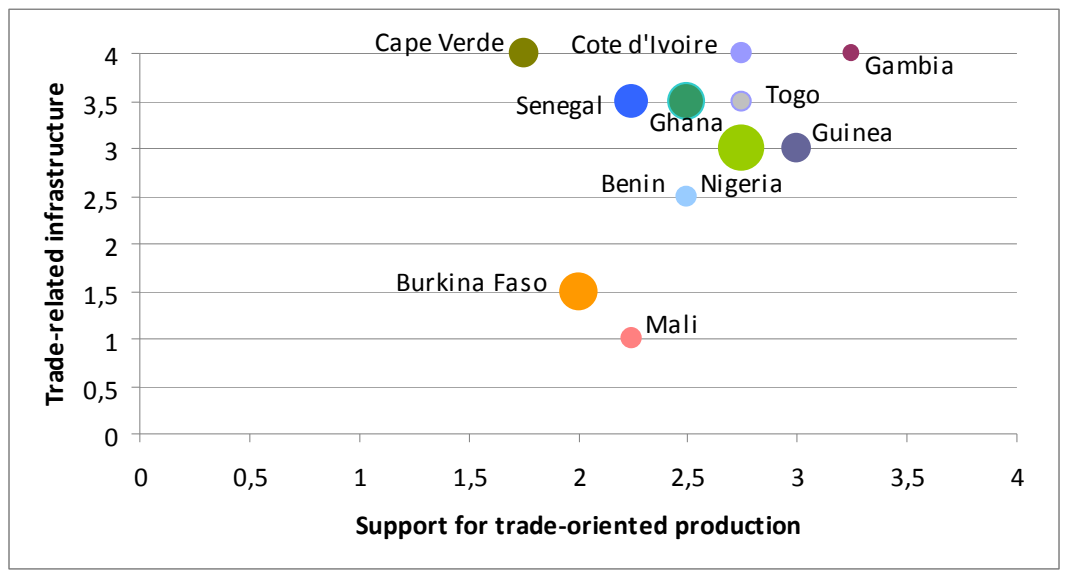

Source: Authors' calculations.

Note: The size of the dots is proportional to countries' need for support for their integration into global markets.

Apart from Kenya, which stands out for its good scores (although it is not well integrated at the regional level), the countries of East Africa are in very similar situations and deserve rather high priority (very few countries have a score above 2.5 in each category). As we saw in Figure 1, this is the region least integrated into international trade, with low exports, value added in industry and services accounting for a low share of GDP, while agricultural value added accounts for a large share. Some of the scores - particularly those relating to the proportion of customs revenue in government revenue, the need for training in trade and infrastructure constraints - are somewhat alarming. From Figure 20, it can be seen that Burundi, Eritrea, Sudan and Rwanda will also need considerable AfT.

Figure 20: AfT needs of East African countries

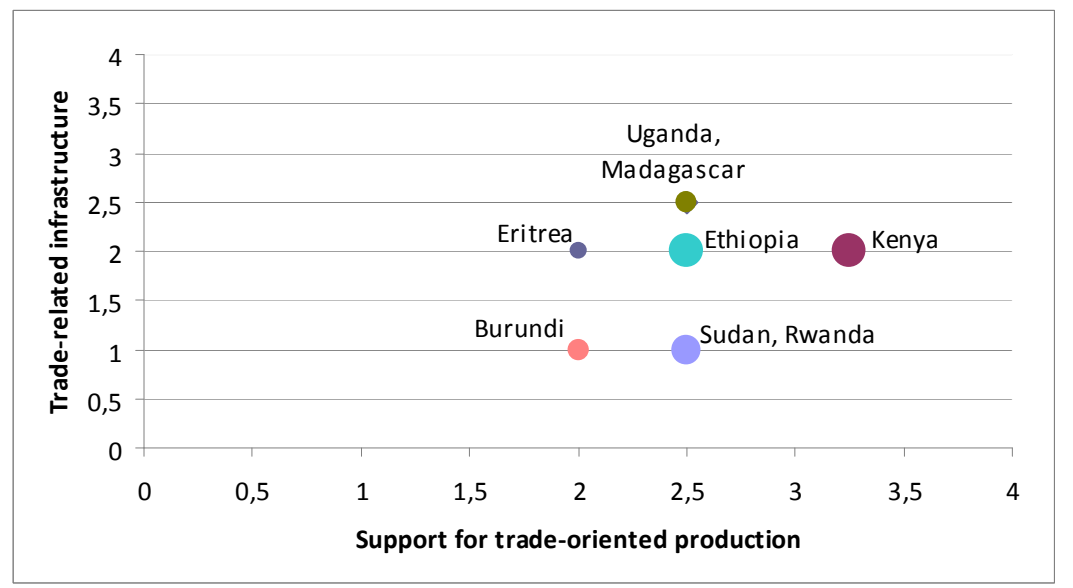

Source: Authors' calculations.

Notes: The size of the dots is proportional to countries' need for support for their integration into global markets.

Uganda and Madagascar are combined, as are Rwanda and Sudan. 
Central Africa seems to be less in need of AfT than are West Africa and East Africa, except where infrastructure is concerned. The countries considered all lack capacity for integration into world trade. This illustrates the low level of diversification of this region, whose trade is primarily connected with oil (see the export concentration index). Nevertheless, the countries of this region display very different needs.

Sao Tome and Principe seems to be the country that requires the most aid, as it receives the lowest scores. Gabon has a low level of integration in regional trade, little import diversification and high trade costs. The Central African Republic needs training in trade policy. Its trade is relatively undiversified, and it scores poorly on the "time required for export" indicator. Lastly, Cameroon is not well integrated at regional level.

Although Chad is not shown in the figure due to lack of data, it is a priority for AfT allocation in this region: its highly concentrated production system, poor infrastructure and need for training in trade matters are all the more worrying in view of its rapid population growth. Similarly, the Democratic Republic of Congo has poor infrastructure and substantial training needs, and the considerable length of time required to start a business is not favourable to trade (see Appendix 4).

Figure 21: AfT needs of Central African countries

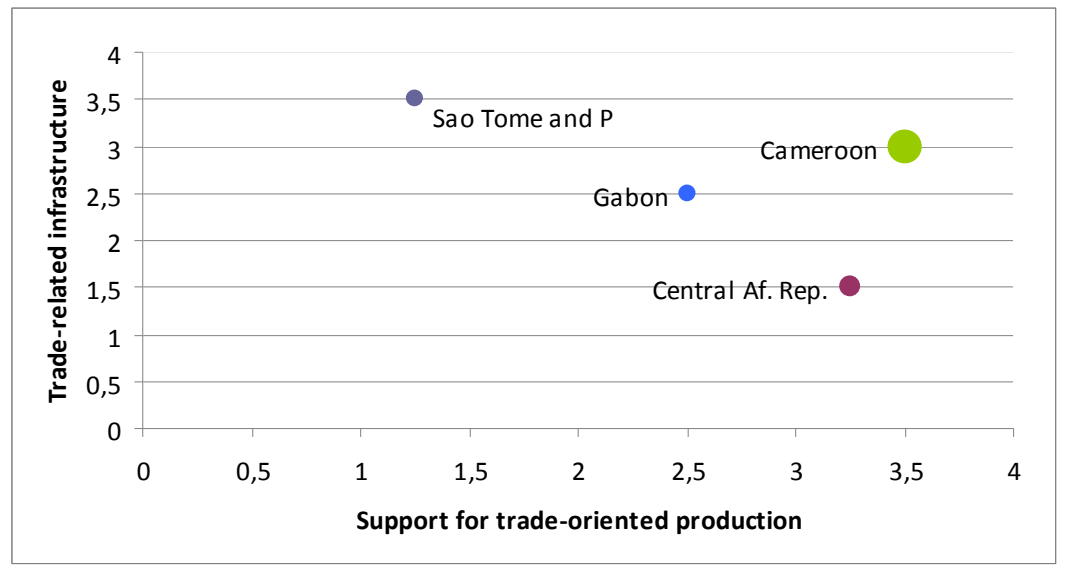

Source: Authors' calculations.

Note: The size of the dots is proportional to countries' need for support for their integration into global markets.

Southern Africa presents a rather varied picture. South Africa stands head and shoulders above the other countries and acts as the locomotive for the regional economy. Angola (not shown due to lack of data) is rather atypical: although its trade situation seems more or less acceptable (see Appendix 4), it still needs aid in all three categories, particularly infrastructure. In the region as a whole, the procedures required for starting a business are lengthy. 
Figure 22: AfT needs of Southern African countries

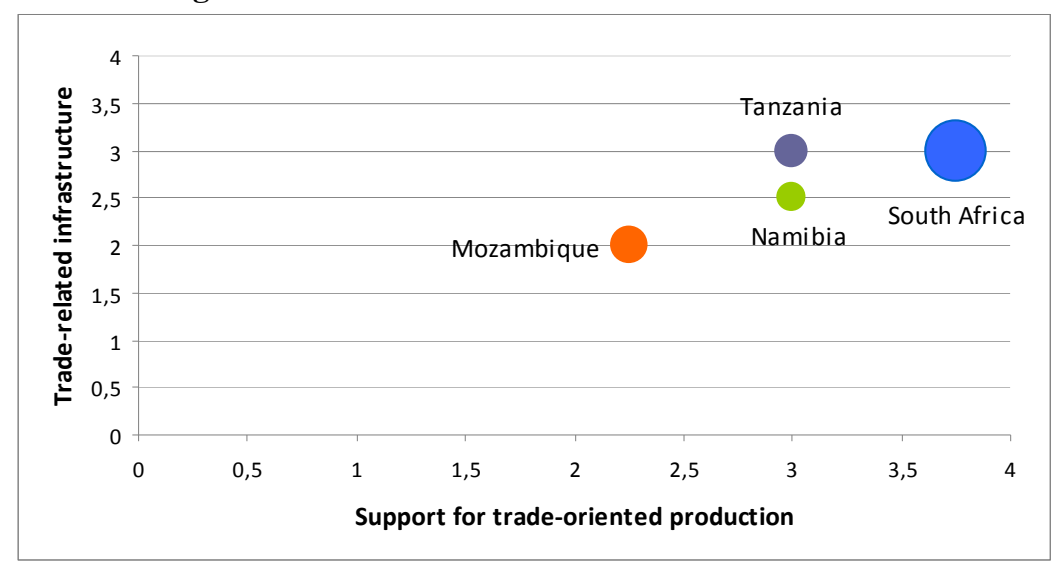

Source: Authors' calculations.

Note: The size of the dots is proportional to countries' need for support for their integration into global markets.

In North Africa, the Maghreb countries are in fairly similar situations: Morocco and Tunisia receive identical scores for all the categories studied, and those of Algeria are fairly close. Only Lebanon is isolated in the figure, owing to its need to build productive capacity. Within this typology, North Africa is the region that has the best trade situation. Productive capacity seems sufficient to cope with projected population growth, in terms of product diversification and administrative procedures required for starting a business. However, regional integration is low (three countries out of four receive a score of only 2 for this parameter). Value added in services in Algeria and Lebanon's trade balance are clearly problem areas (scored 1). Algeria seems to be the country that requires the most assistance for trade integration, particularly in terms of integration into the world trading system and the development of services.

Figure 23: AfT needs of North African countries

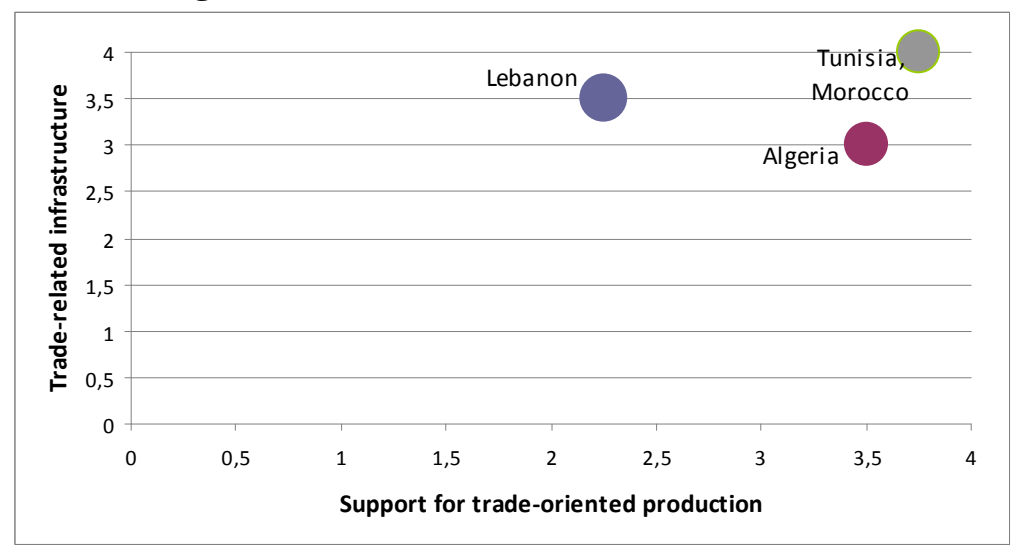

Source: Authors' calculations.

Notes: The size of the dots is proportional to countries' need for support for their integration into global markets.

Morocco and Tunisia are combined. 
ASEAN (the Association of South-East Asian Nations) is not included in this graphical analysis because certain data are lacking. However, a few indications may be given. Exports account on average for $50 \%$ of GDP, and the averages of value added by sector stand at approximately $30 \%$ of GDP owing to the diversity of these countries' sectoral strategies. Among the countries studied, Viet Nam receives the best scores, whereas Laos seems to be in the most difficult situation. Time required for transport and bureaucratic constraints (time required to start a business) would seem to be the areas most in need of support.

To sum up, this typology suggests that the regions most in need of aid for trade are West Africa and East Africa. These results should be regarded with some caution, however, since the list of indicators cannot perfectly reflect the needs of the regions and countries studied. 


\section{Conclusion}

In international fora, a good deal of attention is focused on aid for trade, regarded as a promising tool for development. Although AfT recently received official recognition as an ODA instrument, it still lacks the strategic dimension needed to provide a basis for its effectiveness. Certain DCs are making no progress towards integration in the global marketplace and still have great difficulty in attracting FDI, despite the efforts of their governments to do so. The aim of this paper was thus to present the theory concerning the various categories of aid for trade and to propose a typology of trade-related needs to guide donors in formulating their aid supply strategies. In addition, the paper analyses the linkages between FDI, aid for trade and development. Such a typology is one step to accelerate progress on aid effectiveness. It would allow to improve partnerships between donors and beneficiary countries; indeed, it gives information on priorities. It is thus a mean to improve country ownership also; that gives a signal to the developing country governments on the programs to be supported to progress in the development.

The paper leads to several conclusions. The proposed typology, a tool for identifying the AfT needs of countries and regions, points first to the disparities of such needs across countries and regions, particularly within the regions of West and Southern Africa. Next, the typology reveals that AfT needs are greatest in West and East Africa, and in the category of trade-related infrastructure. Lastly, expanding intra-regional trade is an important issue that will require rethinking of donors' traditional tools, which are too geared towards the national level.

It is necessary to obtain more detailed knowledge of the actual demand for AfT, and this can be done by building the analytical capacity of beneficiary countries and regions. Better knowledge of the trade characteristics of specific industries and markets will enable countries and/or regions to position themselves more effectively on local, regional and world markets. It will also help to improve targeting of beneficiaries and to rehabilitate the link between trade and poverty reduction. This will indisputably require improvements in countries' statistical capacities.

To meet the demand expressed by DCs, it is then up to each donor to identify its comparative advantages and to position itself within the world supply of aid. This will require an evaluation of each donor's AfT projects. Unless these conditions are met, it will not be possible to fulfil the policy commitments made concerning aid for trade, nor the obligations imposed by the WTO and the OECD.

At the global level, whether it is a question of making aid for trade more effective or attracting FDI, greater coherence between the policies of the industrialised countries and those of the DCs is needed. This will require coordination not only among donors but also between private and public stakeholders. Further trade liberalisation alone will not be enough to generate high growth and to improve the geographical and sectoral distribution of FDI.

The reason for this is that although trade policy has its importance, factors such as political stability, the business environment, physical infrastructure, institutions and human capital play a fundamental role. In particular, coherence between trade, sectoral (agricultural, industrial, competition, etc.), macroeconomic and tax policies is essential, within each country and each region. In this context, support for innovation could be one component of aid for trade. These conditions would enable countries to become more integrated into regional and global markets; would create a favourable 
climate for investment, job creation and diversification of economies towards high-growth activities; and most important, would generate income for local populations. 


\section{References}

Acemoglu D., S. Johnson And J.A. Robinson (2000), "Political Losers as a Barrier to Economic Development", American Economic Review, vol. 90, May, pp. 126-44.

AlEXANDRAKI, K. AND H.P. LANKES (2004), “The Impact of Preference Erosion on Middle-Income Developing Countries”, IMF Working Paper WP/04/169.

Anderson, K., W. MARTin AND D. van DER Mensbrugghe (2005), “Agricultural Trade Reform and the Doha Development Agenda", World Bank.

ARvis, J.F, G. RABALlan AND J.F. MARTEAU (2007), “The Cost of Being Landlocked: Logistics Costs and Supply Chain Reliability”, World Bank Policy Research Working Paper 4258, Washington, D.C.

BALE, M.D. (1976), "Estimates of Trade Displacement Costs for US Workers", Journal of International Economics, no. 6, pp. 245-50.

CEPII (2004), "La libéralisation agricole : des effets ambigus sur les pays en développement", $L a$ lettre du CEPII.

Cling, J.P. (2006), “Commerce, croissance, pauvreté et inégalités dans les PED : une revue de la littérature", Document de travail DIAL DT-2006-07, DIAL.

Djankov, S., C. Freund And C. Pham (2006), "Trading on Time”, World Bank Policy Research Working Paper 3909, Washington, D.C.

DupasquiER, C. AND P.N. OsaKwe (2004), "Economic and Statistical Analyses of Trade Capacity Building in Sub-Saharan Africa", ATPC, no. 9.

EASTerly, W. AND R. LeVIne (2003), "New Data, New Doubts: Revisiting 'Aid, Policies, and Growth', Working Paper 26, Center for Global Development.

Fernandez de Cordoba S., S. Laird, J.J. Maur And J.M. Seren (2005), “Adjustment Costs and Trade Liberalization", paper presented at UNCTAD, Geneva, January.

Fontagné, L. AND Y. DeCReuX (2006), “A Quantitative Assessment of the Outcome of the Doha Development Agenda”, CEPII Working Paper.

FOnTAGNE, L. AND J.-L. GUERIN (1997), "L'ouverture, catalyseur de la croissance", Economie Internationale, no. 71.

Frankel, J. AND D. Romer (1999), “Does Trade Cause Growth?”, American Economic Review, vol. 89 , no. 3, pp. 379-99.

Gallup, J.L., J.D. SACHS AND A.D. Mellinger (1999), "Geography and Economic Development”, International Regional Science Review, vol. 22, no. 2, pp. 179-232.

Hall, R. AND C.I. Jones (1999), "Why Do Some Countries Produce so Much More Output per Worker than Others?", Quarterly Journal of Economics, no. 114, pp. 83-116.

HuMmels, D.L. (2000), “Time as a Trade Barrier”, mimeo. 
Kostecki, M. (2001), "Technical Assistance Services in Trade Policy: A Contribution to the Discussion on Capacity Building in the WTO”, ICTSD Resource Paper 2.

Limao, N. AND A.J. Venables (2001), "Infrastructure, Geographical Disadvantage, Transport Costs and Trade", World Bank Economic Review, vol. 15, no. 3, pp. 451-79.

LiPPOLDT, D. AND P. KowALSKI (2005), "Trade Preference Erosion: Expanded Assessment of Countries at Risk of Welfare Losses”, OECD Trade Policy Working Paper no. 20, Paris.

MAGEE, S.P. (1972), "The Welfare Effects of Restriction on U.S. Trade", Brookings Papers on Economic Activity, no. 3, pp. 645-701.

MeLiTZ, M. (2003), "The Impact of Trade on Intra-Industry Reallocations and Aggregate Industry Productivity", Econometrica, vol. 71, pp. 1695-1725.

MendozA, R. AND C. BAKAdur (2002), "Toward Free and Fair Trade: A Global Public Good Perspective", UNDP.

OECD (2002), Foreign Direct Investment for Development: Maximising Benefits, Minimising Costs, OECD, Paris.

POLASKI, S. (2006), "Winners and Losers: Impact of the Doha Round on Developing Countries", Carnegie Endowment, Washington, D.C.

RADELET, S. AND J.D. SACHS (1998), “Shipping Costs, Manufactured Exports, and Economic Growth”, mimeo.

RodrigueZ, F. AND D. RodRIK (2000), “Trade Policy and Economic Growth: A Skeptic's Guide to the Cross-National Evidence”, Working Paper no. 7081, National Bureau of Economic Research, Washington, D.C., May.

RodriK, D., A. Subramanian AND F. TREBbi (2004), "Institutions Rule: The Primacy of Institutions over Geography and Integration in Economic Development", Journal of Economic Growth, vol. 9, no. 2, pp. 131-65.

SACHS, J.D. AND A. WARNER (1995), "Economic Reform and the Process of Global Integration", Brooking Papers on Economic Activity, no. 1, pp. 1-118.

SANER, R. AND L. PAEZ (2001), "Technical Assistance to Least Developed Countries in the Context of the Doha Development Round: High Risk of Failure”, Journal of World Trade, vol. 40, no. 3, pp. 467-94.

Solignac Lecomte, H.B. (2001), "Building Capacity to Trade: A Road Map for Development Partners - Insights from Africa and the Caribbean”, ECDPM Discussion Paper 33, ECDPM, Maastricht.

Stiglitz, J. And A. Charlton (2005), Fair Trade for All: How Trade Can Promote Development, Oxford University Press, New York.

StolPer, W. AND P. SAMUelson (1941), "Protection and Real Wages", Review of Economic Studies, vol. 9.

UNCTAD (2004), “Making Investment Work for Development”, Issues in Brief, no. 5.

UNCTAD (2005), Rethinking the Role of Foreign Direct Investment, Economic Development in Africa series, Geneva. 
UNCTAD (2006a), World Investment Report 2006 - FDI from Developing and Transition Economies: Implications for Development, Geneva.

UNCTAD (2006b), UNCTAD Handbook of Statistics, chap. VII, "International Finance", section 7.3, "Foreign Direct Investment: Inward and Outward Flows and Stocks", Geneva.

UNCTAD (2006c), Least Developed Countries Report 2006: Building Productive Capacities, Geneva.

UNCTAD (2007a), "Foreign Direct Investment Surged Again in 2006", UNCTAD Investment Brief, no. 1.

UNCTAD (2007b), "Recommandations concertées", Trade and Development Board, March.

WiLson, N. AND L. CACHO (2007), "Linkages between Foreign Direct Investment, Trade and Trade Policy - An Economic Analysis with Application to the Food Sector in OECD Countries and Case Studies in Ghana, Mozambique, Tunisia and Uganda", OECD Trade Policy Working Paper no. 50, Paris, March.

Wilson, J.S., C.L. MANN AND T. Otsuki (2004), "Assessing the Potential Benefit of Trade Facilitation: A Global Perspective", World Bank Policy Research Working Paper 3224, Washington, D.C.

WTO (2005), Annual Report, Geneva.

WTO/OECD (2006), “Joint WTO/OECD Report on Trade-Related Technical Assistance and Capacity Building (TRTA/CB)", Paris and Geneva. 


\section{Appendix 1: Categories of $\mathrm{AfT}^{27}$}

Donors declare their AfT contributions each year to the WTO and the OECD, classifying their projects in categories and sub-categories. To draw up this classification, they use the following definitions, which allow them to identify the categories to their projects belong. The first two categories are defined in great detail because they have existed for some time; the other four have not yet been described in detail owing to their unofficial nature (definition is in progress).

We list below the objectives of projects covered by these categories.

\section{1 - Trade policy and regulations}

\section{Dispute settlement}

Customs valuation

Technical barriers to trade

\section{Sanitary and phytosanitary} measures

Trade mainstreaming in PRSPs/development plans

Trade-related intellectual property rights

Agriculture

Services
Better understanding of rights and obligations in the WTO framework; access to legal advice.

Determination of the customs value of imported goods; elimination of arbitrary and fictitious values.

Improved understanding of rights and obligations vis-à-vis the WTO concerning the use of technical regulations, standards and compliance assessment procedures.

Assistance concerning food safety, measures to protect the health of livestock and plants, as well as understanding of the rights and obligations contained in the Agreement on the Application of Sanitary and Phytosanitary Measures.

Awareness raising; strengthening of trade policy; mainstreaming trade in development and poverty reduction strategies.

Negotiations, formulation of laws and regulations on the protection of copyrights, brands and trademarks, patents, industrial designs and models, business secrets; prevention of unauthorised use of the above; strengthening of intellectual property offices.

Implementation of the Agriculture Agreement; negotiations on liberalisation of markets for farm products; impact studies.

Implementation of the General Agreement on Trade in Services (GATS); negotiations on international trade in services; identification of markets; inventory of issues affecting trade in services.

\footnotetext{
${ }^{27}$ As proposed by the Task Force on Aid for Trade in July 2006. These categories will be official as soon as they are accepted by the WTO member countries.
} 
Tariff negotiations - nonagricultural market access

Rules

Trade and environment

Trade and investment

Trade and competition

Trade facilitation

Transparency and government procurement

Accession

Tariff reforms

Training in trade negotiation techniques

Regional trade agreements (RTAs)

\section{Trade-related training/} education
Implementation of agreements on corrective measures of contingent protection; negotiations on the reduction or elimination of customs duties, tariff peaks and tariff escalation on non-agricultural products.

Negotiation and formulation of laws and regulations on anti-dumping, subsidies, countervailing and safeguard measures; clarification and improvement of disciplines concerning unfair trade practices; support for the authorities responsible for investigations.

Building capacity in the field of trade and environment, for example, at national policy level, through increased coherence between trade and environmental bodies.

Implications of closer multilateral co-operation in the field of trade and investment for development.

Support for gradual strengthening of the institutions responsible for competition, strengthening of antitrust laws and elimination of local monopolies.

Simplification and harmonisation of international trade procedures (customs or licensing procedures, formalities relating to transport, payments, insurance etc.); support for customs services.

Identification of negotiating options concerning transparency in government procurement; drafting of legislation; strengthening of the bodies responsible for awarding public contracts.

Identification of changes needed to laws, regulations and procedures to complete the negotiations on the terms of accession to the WTO; familiarization with the WTO.

Establishment of simple, transparent, low and uniform tariff schedules that reduce discrimination between output intended for the domestic market and output for export markets, and between purchasing of domestic products and foreign products.

Establishment of specialised, individualised programmes to train trade negotiators.

Support for RTAs (SACU, ASEAN, FTAA, ACP/EU Agreement, etc.); formulation of rules of origin and clauses relating to special and differentiated treatment in the RTA.

Development of human resources in trade-related sectors not covered by one of the above-mentioned codes; university programmes on trade. 


\section{2 - Trade development}

Business support services and institutions

\section{Public-private sector networking}

\section{E-commerce}

\section{Trade finance}

Trade promotion strategy design and implementation

\section{Market analysis and development}

Support for trade and business organisations and chambers of commerce; support for legal and regulatory reforms aimed at improving the business environment and investment climate; building institutional capacity in the private sector and provision of consulting services; trade information.

Proposals for instruments and mechanisms to improve dialogue and resource sharing between the public and private sectors (and within the private sector), including trade shows, at the national, regional and global levels.

Promotion of information and communication technology as a means of increasing trade; provision of software, hardware and training to increase countries' e-commerce capabilities.

Access to trade finance; support for reform of financial systems, banking markets and securities markets to facilitate trade; laws and regulations that protect and encourage trade-related investment.

Support for the formulation of a sector-by-sector trade strategy at national level; upgrading skills of the labour force in export sectors; implementation of sectoral strategies relating to products in the agriculture, forestry, fishing, manufacturing, extractive, tourism and services sectors, including equitable trade programmes.

Access to market information; advice on standards, packaging, quality control, marketing and distribution networks in the agriculture, forestry, fishing, manufacturing, extractive, tourism and services sectors. 


\section{3 - Trade-related infrastructure}

The projects classified in this category are those concerned with transport for trade-related purposes, communications and energy.

Transport and storage

Communications

Energy
Support for activities relating to the construction, use or management of road, rail, water and air transport systems, including storage.

Support for the establishment of communications systems with a view to promoting trade (postal services, telecommunications, radio, television, written press, etc.).

Support for promotion of peaceful and ODA-eligible uses of nuclear energy (construction or decommissioning of civil nuclear power plants, development or provision of medical isotopes, irradiation of food and other industrial and business applications). Nuclear weapons research and military applications of nuclear technology are excluded.

\section{4 - Trade-related adjustment}

Projects in this category are contributions made to the general budget of the beneficiary government to support implementation of trade reform projects and meet adjustment costs stemming from changes in national and international trade policy.

A few examples: assistance in managing balance-of-payments deficits due to the changes in the world trade environment (costs stemming from preference erosion, from loss of customs revenue and from increases in food prices), aid to ease the transition to a liberalised environment (cost of establishing a new trade integration mechanism within the framework of the international financial institutions, cost of operationalising AfT, etc.). 


\section{5 - Building productive capacity}

Projects in this category are aimed at enhancing productivity and output.

Business and other services

Banking and financial services

Agriculture

Forestry

Fishing

Industry

Mining

Tourism
Promotion of business and improvement of the business environment and privatisation context.

Support for banking and financial services in both the formal and informal sectors.

Support for agricultural policy, agricultural development and means of production, soil management, management of water resources for agricultural use, crops and livestock, agrarian reform, credit, agricultural cooperatives and research, and veterinary services.

Support for forest policy, forestry planning, firewood and charcoal production projects, forestry-related education, research and development.

Support for fisheries policy and planning and for fishery-related research and education.

Support for industrial policy and the development of small and microbusinesses; all types of manufacturing are concerned, including the food industry, manufacture of chemicals and fertilisers, gas liquefaction and oil refining, production of firewood, textiles and leather.

Support for policies and planning in regard to mining of ores and minerals, geology and extraction of ores, minerals and fuels.

Support for tourism policy and administrative management of tourist businesses.

\section{6 - Other trade-related needs}

This catch-all category is included to allow for the possibility that the definition of AfT will be broadened, as well as for trade-related needs not mentioned above. 
Appendix 2: Respective shares of multilateral and bilateral contributions to AfT
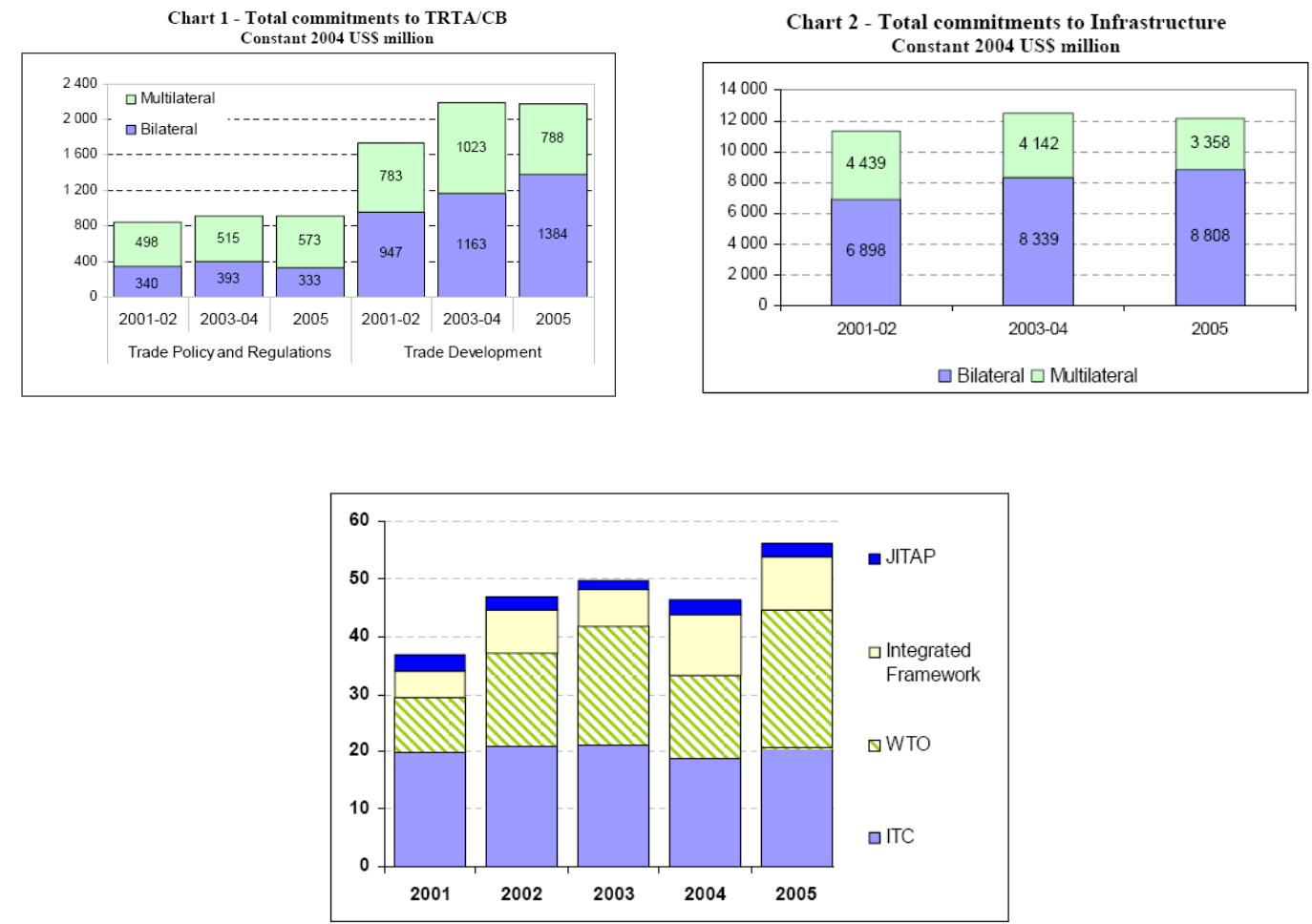

Source: WTO/OECD (2006). 
These economic regions group the countries in the most reasonable manner given the existing trade partnerships and the institutional context: the Barcelona process ${ }^{28}$ and the zones used for the Economic Partnership Agreement (EPA) $)^{29}$ negotiations with Africa and the Caribbean, which aim to liberalise trade with the European Union. ASEAN is used for the Asian region.

\section{Africa:}

North Africa: Morocco, Algeria, Tunisia, Libya, Egypt, Turkey, Autonomous Palestinian Territories ${ }^{30}$, Lebanon, Israel.

West Africa: Senegal, Gambia, Cape Verde, Guinea, Guinea-Bissau, Equatorial Guinea, Sierra Leone, Liberia, Ghana, Burkina Faso, Côte d'Ivoire, Mali, Niger, Togo, Nigeria, Mauritania, Benin.

Central Africa: Democratic Republic of Congo, Congo, Gabon, Central African Republic, Cameroon, Chad, Sao Tome and Principe.

East Africa: Madagascar, Kenya, Somalia, Uganda, Ethiopia, Djibouti, Eritrea, Sudan, Rwanda, Burundi, Comoros.

Southern Africa: South Africa, Lesotho, Swaziland, Mozambique, Zimbabwe, Botswana, Namibia, Zambia, Malawi, Tanzania, Angola.

\footnotetext{
${ }^{28}$ The Euro-Mediterranean partnership, known as the Barcelona process, was initiated at the Barcelona Conference of 27. 28 November 1995. It comprises the 25 member states of the European Union and 10 countries on the southern and eastern sides of the Mediterranean Sea. Its objectives are:

- to build an area of shared peace and stability through enhanced policy and security dialogue;

- to build an area of shared prosperity through economic and financial partnership and the establishment of a free trade area;

- to bring the peoples of the region closer together through social, cultural and human partnership designed to encourage understanding of other cultures and communication between civil societies.

${ }^{29}$ The Cotonou Agreement sounded the death-knell of preferential agreements by calling for a revamped partnership, based on reciprocity, between the European Union and six regions composed of African, Caribbean and Pacific (ACP) countries. These EPAs are in a better position to meet the new challenges of globalisation and the legal constraints of the World Trade Organisation. Supposedly, the negotiation process will be completed in 2007 and the Agreement will come into effect on 1 January 2008 , but it is unclear whether this schedule will be met.

${ }^{30}$ Very few data are available for this country.
} 


\section{$\underline{\operatorname{ASEAN}^{31} \text { (Association of South-East Asian Nations): }}$}

Indonesia, Malaysia, Philippines, Singapore, Thailand, Brunei, Viet Nam, Myanmar, Laos, Cambodia.

\section{Caribbean:}

Antigua and Barbuda, Bahamas, Barbados, Cuba, Dominican Republic, Dominica, Grenada, Haiti, Jamaica, St. Lucia, St. Kitts-Nevis, St. Vincent and the Grenadines, Trinidad and Tobago.

\footnotetext{
${ }^{31}$ ASEAN was created in 1967 by Indonesia, Malaysia, the Philippines, Singapore and Thailand in the context of the Viet Nam war. Its initial priority was the fight against communism, but since then its nature has gradually changed. The Asian financial and economic crisis of 1997-98, the reduced participation of Indonesia, which had been one of the lynchpins of ASEAN, and the accession of the weakest countries in the region (the so-called CLMV countries: Cambodia, Laos, Myanmar, Viet Nam) have shaken regional co-operation and integration. The member countries face the challenge of building ASEAN's institutional, human and financial capacity and expanding the role of its secretariat, which currently has only an administrative function. In 2003, the Bali Concord II set a target of 2020 for the implementation of ASEAN's three pillars - a security community, an economic community and a socio-cultural community - which are supposed to foster the emergence of a community of South-East Asian nations. The fact is that the member countries face increasingly complex issues today in the areas of regional security (international terrorism, territorial disputes in the South China Sea, maritime piracy), economic co-operation (competition from China and India, endless negotiations over free trade agreements), health (bird flu, SARS) and the environment (transnational pollution) - issues that they are striving to address through regional approaches.
} 
Appendix 4: Results of the typology

\begin{tabular}{|c|c|c|c|c|c|c|c|c|c|}
\hline & \multicolumn{5}{|c|}{ Country characteristics } & \multicolumn{4}{|c|}{ Building productive capacity } \\
\hline & & $\begin{array}{l}\text { Exports of } \\
\text { goods and } \\
\text { services (\% of } \\
\text { GDP) } \\
\end{array}$ & $\begin{array}{l}\text { Value added } \\
\text { in } \\
\text { agriculture } \\
\text { (\% of GDP) }\end{array}$ & $\begin{array}{l}\text { Value } \\
\text { added in } \\
\text { industry } \\
\text { (\% of GDP) }\end{array}$ & $\begin{array}{l}\text { Value } \\
\text { added in } \\
\text { services } \\
\text { (\% of } \\
\text { GDP) } \\
\end{array}$ & $\begin{array}{l}\text { Trade } \\
\text { bal. }\end{array}$ & $\begin{array}{l}\text { (pop2050- } \\
\text { pop2006) } \\
\text { / pop2006 }\end{array}$ & $\begin{array}{c}\text { Time } \\
\text { required to } \\
\text { start up a } \\
\text { business } \\
\text { (days) }\end{array}$ & $\begin{array}{c}\text { Export } \\
\text { concentration } \\
\text { index }\end{array}$ \\
\hline \multirow{4}{*}{$\begin{array}{l}\text { North } \\
\text { Africa }\end{array}$} & Morocco & 3 & 3 & 3 & 3 & 3 & 4 & 4 & 4 \\
\hline & Algeria & 3 & 4 & 4 & 1 & 4 & 4 & 4 & 2 \\
\hline & Tunisia & 4 & 4 & 3 & 4 & 3 & 4 & 4 & 4 \\
\hline & Lebanon & 2 & 4 & 3 & 4 & 1 & 4 & 3 & 1 \\
\hline \multirow{17}{*}{$\begin{array}{l}\text { West } \\
\text { Africa }\end{array}$} & Senegal & 3 & 3 & 2 & 4 & 2 & 3 & 2 & 2 \\
\hline & Gambia & 4 & 2 & 1 & 4 & 3 & 3 & 4 & 3 \\
\hline & Cape Verde & 3 & 4 & 2 & 4 & 1 & 2 & 2 & 2 \\
\hline & Guinea & 2 & 3 & 4 & 2 & 4 & 2 & 3 & 3 \\
\hline & Eq. Guinea & & 4 & 4 & 1 & 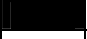 & 2 & 1 & 1 \\
\hline & Guinea-Bissau & 3 & 1 & 1 & 1 & 1 & 1 & 1 & 2 \\
\hline & Sierra Leone & 2 & & & & 1 & 3 & 4 & 1 \\
\hline & Liberia & 2 & 1 & 1 & 3 & 2 & 1 & & \\
\hline & Ghana & 4 & 2 & 3 & 2 & 2 & 3 & 2 & 3 \\
\hline & Burkina Faso & 1 & 2 & 2 & 3 & 2 & 1 & 3 & 2 \\
\hline & Côte d'Ivoire & 4 & 3 & 2 & 4 & 4 & 3 & 3 & 1 \\
\hline & Mali & 3 & 2 & 3 & 1 & 3 & 1 & 3 & 2 \\
\hline & Niger & 1 & 2 & 4 & 2 & 3 & 1 & 4 & 1 \\
\hline & Nigeria & 4 & 3 & 4 & 1 & 4 & 2 & 3 & 2 \\
\hline & Togo & 3 & 2 & 2 & 2 & 2 & 3 & 2 & 4 \\
\hline & Mauritania & 3 & 3 & 4 & 3 & 1 & 2 & 1 & 1 \\
\hline & Benin & 1 & 2 & 1 & 3 & 2 & 2 & 3 & 3 \\
\hline \multirow{7}{*}{$\begin{array}{l}\text { Central } \\
\text { Africa }\end{array}$} & Congo, Rep. & 4 & 4 & 4 & 1 & 4 & 1 & 2 & \\
\hline & DRC & 2 & 1 & 2 & 1 & 4 & 2 & 1 & 2 \\
\hline & Gabon & 4 & 4 & 4 & 1 & 4 & 3 & 2 & 1 \\
\hline & $\begin{array}{l}\text { Central African } \\
\text { Republic } \\
\end{array}$ & 1 & 1 & 3 & 1 & 4 & 3 & 4 & 2 \\
\hline & Cameroon & 2 & 1 & 1 & 2 & 4 & 4 & 3 & 3 \\
\hline & Chad & 2 & 1 & 1 & 2 & 1 & 1 & 2 & \\
\hline & $\begin{array}{l}\text { Sao Tome and } \\
\text { Principe } \\
\end{array}$ & 4 & 3 & 1 & 4 & 1 & 2 & 1 & 1 \\
\hline \multirow{9}{*}{$\begin{array}{c}\text { East } \\
\text { Africa }\end{array}$} & Madagascar & 2 & 2 & 1 & 3 & 2 & 1 & 4 & 3 \\
\hline & Kenya & 2 & 2 & 1 & 3 & 3 & 4 & 2 & 4 \\
\hline & Uganda & 1 & 2 & 2 & 3 & 2 & 1 & 3 & 4 \\
\hline & Eritrea & 1 & 3 & 3 & 4 & 1 & 2 & 2 & 3 \\
\hline & Ethiopia & 1 & 1 & 1 & 2 & 1 & 2 & 4 & 3 \\
\hline & Rwanda & 1 & 1 & 2 & 2 & 1 & 2 & 4 & 3 \\
\hline & Sudan & 1 & 1 & 2 & 2 & 3 & 3 & 3 & 1 \\
\hline & Burundi & 1 & 1 & 2 & 1 & 2 & 1 & 3 & 2 \\
\hline & Comoros & 1 & 1 & 1 & 3 & 2 & 1 & 4 & 1 \\
\hline \multirow{6}{*}{$\begin{array}{l}\text { Southern } \\
\text { Africa }\end{array}$} & South Africa & 3 & 4 & 4 & 4 & 4 & 4 & 3 & 4 \\
\hline & Mozambique & 3 & 3 & 3 & 3 & 2 & 4 & 1 & 2 \\
\hline & Zimbabwe & 2 & 3 & 2 & 4 & 3 & 4 & 1 & \\
\hline & Namibia & 4 & 4 & 3 & 4 & 4 & 4 & 1 & 3 \\
\hline & Tanzania & 2 & 1 & 1 & 2 & 3 & 3 & 3 & 3 \\
\hline & Angola & 4 & 4 & 4 & 1 & 4 & 1 & 1 & 1 \\
\hline ASEAN & Cambodia & 4 & 2 & 3 & 2 & 2 & 2 & 1 & 4 \\
\hline
\end{tabular}




\begin{tabular}{|c|l|c|c|c|c|c|c|c|c|}
\multirow{2}{*}{} & Laos & 3 & 1 & 3 & 1 & 3 & 3 & 1 \\
\cline { 2 - 9 } & Viet Nam & 4 & 3 & 4 & 2 & 3 & 4 & 2 \\
\hline \multirow{2}{*}{ Caribbean } & Dom. Rep. & 4 & 4 & 3 & 4 & 4 & 4 & 2 \\
\cline { 2 - 10 } & Haiti & 1 & 2 & 2 & 3 & 1 & 3 & 1 \\
\hline \multirow{2}{*}{ Other } & Suriname & 2 & 4 & 4 & 4 & 1 & 4 & 1 \\
\cline { 2 - 10 } & Yemen, Rep. & 3 & 3 & 4 & 3 & 3 & 1 & 4 \\
\hline
\end{tabular}

\begin{tabular}{|c|c|c|c|c|c|c|c|c|}
\hline & & \multicolumn{5}{|c|}{ Integration into international trade } & \multicolumn{2}{|c|}{ Infrastructure } \\
\hline & & $\begin{array}{c}\text { Customs } \\
\text { revenue }\end{array}$ & $\begin{array}{l}\text { Estimated } \\
\text { need for } \\
\text { training in } \\
\text { trade } \\
\text { negotiations }\end{array}$ & $\begin{array}{c}\text { Regional } \\
\text { integration }\end{array}$ & $\begin{array}{l}\text { Geographical } \\
\text { diversification } \\
\text { of imports }\end{array}$ & $\begin{array}{l}\text { Geographical } \\
\text { diversification } \\
\text { of exports }\end{array}$ & $\begin{array}{l}\text { Time } \\
\text { req. for } \\
\text { exp. }\end{array}$ & $\begin{array}{l}\text { Cost of } \\
\text { exp. }\end{array}$ \\
\hline \multirow{4}{*}{$\begin{array}{l}\text { North } \\
\text { Africa }\end{array}$} & Morocco & 4 & 4 & 1 & 3 & 3 & 4 & 4 \\
\hline & Algeria & 4 & 2 & 2 & 3 & 3 & 4 & 2 \\
\hline & Tunisia & 4 & 4 & 2 & 1 & 2 & 4 & 4 \\
\hline & Lebanon & 4 & 3 & 2 & 4 & 4 & 4 & 3 \\
\hline \multirow{17}{*}{$\begin{array}{l}\text { West } \\
\text { Africa }\end{array}$} & Senegal & 3 & 2 & 3 & 2 & 3 & 4 & 3 \\
\hline & Gambia & 1 & 2 & 2 & 2 & 2 & 4 & 4 \\
\hline & Cape Verde & 2 & 3 & 2 & 1 & 2 & 4 & 4 \\
\hline & Guinea & 3 & 1 & 2 & 3 & 3 & 2 & 4 \\
\hline & Eq. Guinea & 4 & 1 & & & & 3 & 2 \\
\hline & Guinea-Bissau & 1 & 1 & & & & 3 & 2 \\
\hline & Sierra Leone & & 1 & 4 & 1 & 4 & 3 & 1 \\
\hline & Liberia & 2 & 1 & & & & & \\
\hline & Ghana & 2 & 3 & 2 & 4 & 4 & 4 & 3 \\
\hline & Burkina Faso & 3 & 2 & 4 & 2 & 1 & 1 & 2 \\
\hline & Côte d'Ivoire & 1 & 3 & 3 & 1 & 3 & 4 & 4 \\
\hline & Mali & 1 & 2 & 4 & 2 & 1 & 1 & 1 \\
\hline & Niger & 1 & 1 & 4 & 3 & 2 & & \\
\hline & Nigeria & 4 & 2 & 1 & 4 & 4 & 3 & 3 \\
\hline & Togo & 1 & 1 & 4 & 4 & 4 & 3 & 4 \\
\hline & Mauritania & & 1 & 1 & 1 & 3 & 3 & 1 \\
\hline & Benin & 1 & 2 & 3 & 3 & 3 & 2 & 3 \\
\hline \multirow{7}{*}{$\begin{array}{l}\text { Central } \\
\text { Africa }\end{array}$} & Congo, Rep. & 4 & 1 & \multirow[t]{2}{*}{-} & & 1 & 2 & 2 \\
\hline & DRC & 2 & 1 & & & & 1 & 1 \\
\hline & Gabon & 2 & 2 & 1 & 1 & 3 & 4 & 1 \\
\hline & $\begin{array}{l}\text { Central African } \\
\text { Republic } \\
\end{array}$ & 3 & 1 & 3 & 1 & 1 & 1 & 2 \\
\hline & Cameroon & 3 & 2 & 1 & 3 & 3 & 2 & 4 \\
\hline & Chad & 3 & 1 & & & 2 & 1 & 1 \\
\hline & $\begin{array}{l}\text { Sao Tome and } \\
\text { Principe }\end{array}$ & 3 & 1 & 1 & 1 & 1 & 3 & 4 \\
\hline \multirow{9}{*}{$\begin{array}{l}\text { East } \\
\text { Africa }\end{array}$} & Madagascar & 1 & 2 & 1 & 4 & 2 & 2 & 3 \\
\hline & Kenya & 2 & 3 & 1 & 4 & 4 & 3 & 1 \\
\hline & Uganda & 1 & 2 & 3 & 2 & 4 & 2 & 3 \\
\hline & Eritrea & 2 & 1 & 2 & 2 & 3 & 1 & 3 \\
\hline & Ethiopia & 2 & 2 & 2 & 4 & 4 & 2 & 2 \\
\hline & Rwanda & 3 & 2 & 4 & 2 & 2 & 1 & 1 \\
\hline & Sudan & 3 & 1 & 1 & 4 & 1 & 1 & 1 \\
\hline & Burundi & 2 & 1 & 3 & 3 & 1 & 1 & 1 \\
\hline & Comoros & 1 & 1 & & & 1 & 3 & 2 \\
\hline \multirow{2}{*}{$\begin{array}{c}\text { Southern } \\
\text { Africa }\end{array}$} & South Africa & 4 & 4 & 2 & 4 & 4 & 3 & 3 \\
\hline & Mozambique & 3 & 2 & 4 & 2 & 2 & 2 & 2 \\
\hline
\end{tabular}




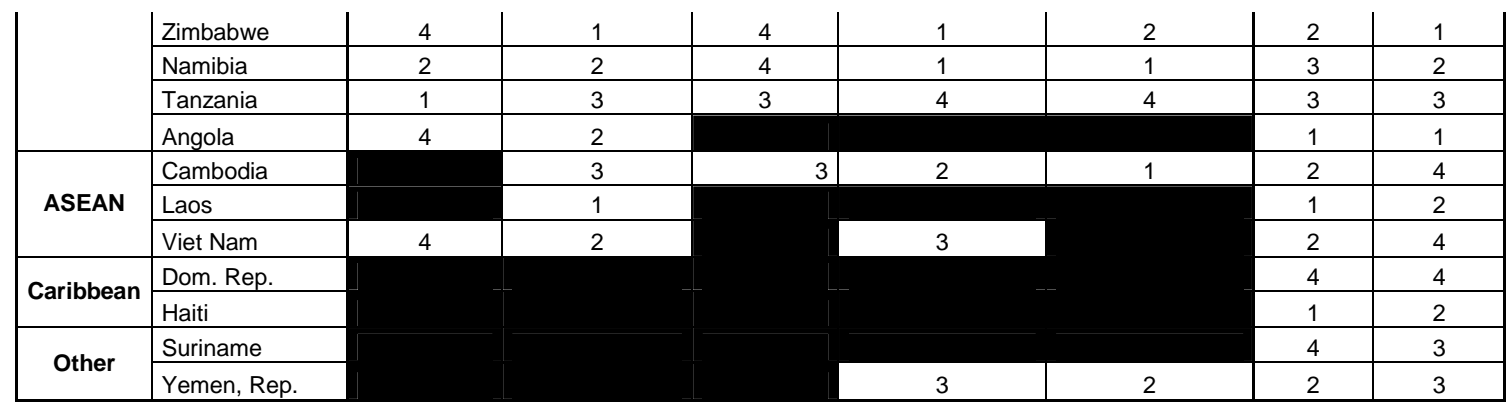

Note: Blacked-out cells indicate lack of data. 